\title{
Drivers of the variability of dimethylsulfonioproprionate (DMSP) and dimethylsulfoxide (DMSO) in the Southern North Sea
}

\author{
C. Royer $^{\text {a,b, }}{ }^{*}$, A.V. Borges ${ }^{b}$, J. Lapeyra Martin ${ }^{\text {a }}$, N. Gypens ${ }^{\text {a }}$ \\ ${ }^{a}$ Laboratoire d'Ecologie des Systèmes Aquatiques, Université Libre de Bruxelles, CP221, Boulevard du Triomphe, Brussels, 1050, Belgium \\ ${ }^{\mathrm{b}}$ Unité d'Océanographie Chimique, Institut de Physique (B5A), Université de Liège, Liège, 4000, Belgium
}

\section{A R T I C L E I N F O}

\section{Keywords:}

Dimethylsulfoniopropionate

Dimethylsulfoxide

Phytoplankton diversity

Southern North Sea

\begin{abstract}
A B S T R A C T
The influence of abiotic and biotic factors on the concentration of dimethylsulfoniopropionate (DMSP) and dimethylsulfoxide (DMSO) was investigated and compared during two annual cycles in 2016 and 2018 in the Belgian coastal zone (BCZ) in the southern North Sea at five fixed stations. These stations covered a near-offshore gradient from stations close to the mouth of the Scheldt estuary to most offshore stations. Significant differences of Chlorophyll- $a$ (Chl- $a$ ) concentrations were observed between the two years with higher values in early spring 2018 (due to better light and nutrient conditions coupled to colder temperatures) and in summer 2018 (due to warmer conditions) compared to 2016. Nevertheless, the seasonal and spatial DMSP and DMSO (DMS(P,O)) patterns, as well as the yearly average were nearly identical in 2016 and 2018. This can be explained by the fact that the phytoplankton groups responsible for the large differences in Chl- $a$ in 2018 and 2016 were low DMSPproducers characterized by several diatom and dinoflagellate species, occurring in early spring and summer. Further, the Prymnesiophyceae Phaeocystis globosa, occurring in late spring and responsible of most of DMS(P,O) measured in the area, reached similar biomass both years. The DMSP:Chl- $a$ ratio obtained from the field measurements were similar to those previously published for the main observed phytoplankton groups, but more differences were observed for the DMSO:Chl- $a$ ratio. DMS $(\mathrm{P}, \mathrm{O})$ estimations based on Chl- $a$ linear regressions for the whole dataset need to account on two relationships discriminating the low and high-DMSP producing species.
\end{abstract}

\section{Introduction}

Dimethylsulfoniopropionate (DMSP; $\left(\mathrm{CH}_{3}\right)_{2} \mathrm{~S}^{+} \mathrm{CH}_{2} \mathrm{CH}_{2} \mathrm{COO}^{-}$) and dimethylsulfoxide (DMSO; $\left(\mathrm{CH}_{3}\right)_{2} \mathrm{SO}$ ) are organic sulfur compounds produced by numerous species of marine micro-algae. DMSP is the main precursor of the climate active gas dimethylsulfide (DMS) that once in the atmosphere might affect the Earth's radiative budget (Charlson et al., 1987; Quinn and Bates, 2011). Prymnesiophyceae and Dinophyceae are high-DMSP producers, and the low-DMSP producers include some members of Chrysophyceae and diatoms (Keller et al., 1989; McParland and Levine, 2019). The intracellular physiological functions of DMS $(\mathrm{P}, \mathrm{O})$ are still poorly understood. DMSP might play roles such as antioxidant (Sunda et al., 2002), cryoprotector, osmolyte (Kirst et al., 1991; Bucciarelli and Sunda, 2003), methyl donor (Kirst, 1996), zooplankton deterrent (Wolfe et al., 1997; Strom et al., 2003), or signaling compound (Stefels, 2000; Seymour et al., 2010). DMSO could be involved in a complex cascade reaction in the antioxidant system alongside with DMS and acrylate (Sunda et al., 2002). The DMS(P,O) production by marine micro-algae varies considerably depending on the growth stage, salinity, temperature, nutrient availability, and light intensity. Seawater phytoplankton diversity is the factor that affects the most DMSP production (Townsend and Keller, 1996; Stefels et al., 2007). Phytoplankton composition and its seasonal succession might depend on the seasonal change in day length (Litchman and Klausmeier, 2001), although water temperature has been found to be the most significant factor affecting the phytoplankton community structure in some parts of the globe (Suikkanen et al., 2007). Changes in temperature will affect the growth-irradiance relationship (Edwards et al., 2016) and the competitive dominance of algal communities (Striebel et al., 2016) which is a key factor for the species' composition (Schabhüttl et al., 2013). In deeper pelagic systems, the influence of increasing temperature on thermal stratification induces an increase in light availability that is usually the phytoplankton bloom trigger (Wiltshire et al., 2008; Sommer et al., 2012). In well-mixed coastal waters, stratification rarely plays a role, and the amount of light will be the limiting factor rather than the nutrients concentration (Wiltshire et al., 2008). The spring

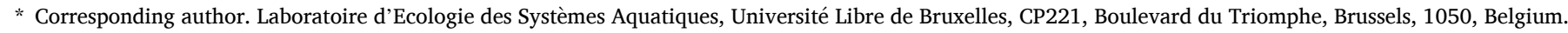

E-mail address: croyer@ulb.ac.be (C. Royer).
} 
phytoplankton seasonal succession will also depend on the Sea Surface Temperature (SST) during winter influencing the overwintering zooplankton and its grazing pressure (Sommer and Lewandowska, 2011).

SST has increased in the North Sea since the 1980s affecting the physiology, abundance, and phenology of marine phytoplankton (Richardson and Schoeman, 2004; Hunter-Cevera et al., 2016; Barton et al., 2018). In addition, high anthropogenic loads of inorganic nutrients (nitrogen and phosphorus) led to important phytoplankton blooms and biomass in most coastal zones between March and October (Desmit et al., 2019). In the Southern North Sea, the Belgian Coastal Zone (BCZ) is a eutrophic and well-mixed area under the influence of the Scheldt and the Rhine rivers. It is characterized by a very high phytoplankton biomass and three phytoplankton blooms: (1) the first occurs in late February-March with diatoms, (2) directly followed by a huge biomass peak of Phaeocystis globosa in April-May, and (3) another diatom bloom at the end of summer-beginning of autumn (Rousseau et al., 2002). This phytoplankton taxonomic succession was very constant from 1988 to 2000 despite the variability in salinity, temperature, and light (Rousseau et al., 2002). The onset of the diatom spring bloom in the BCZ is dependent on a specific light threshold. Furthermore, the adaptation to low irradiance and temperature prevailing in late winter-early spring coupled with high nutrient concentrations explains the first diatom bloom, followed by Phaeocystis globosa when the ambient dissolved silicate is depleted (Rousseau et al., 2002). Phaeocystis globosa blooms are responsible for $95 \%$ of the phytoplankton late spring community biomass (Rousseau et al., 1990, 2000). Yet, since 1990, de-eutrophication measures have led to the decrease of nutrient concentrations in coastal waters of the Southern North Sea (van Beusekom et al., 2009; Prins et al., 2012). Both the warming and the de-eutrophication trends may have an impact on the long-term annual mean of Chl- $a$ (Desmit et al., 2019) and the phytoplankton community (Nohe et al., 2020). This should also affect the DMS(P,O) concentrations, since they strongly depend on phytoplankton composition and biomass, as shown by a modelling study in the area (Gypens et al., 2014). A better understanding of the intracellular DMS $(\mathrm{P}, \mathrm{O})$ concentration in response to external drivers or phytoplankton diversity could improve their prediction, and ultimately the related DMS emissions with its potential climate effect (Charlson et al., 1987).

This study presents an interannual comparison of DMS(P,O) concentrations measured in the BCZ in 2016 and 2018 on a regular grid of 5 fixed stations. The year-to-year variation was analyzed in light of nutrient concentrations, SST, and light availability; the key factors influencing the phytoplankton production and community structure in general and in the study area (Nohe et al., 2020). The phytoplankton composition was studied for both years to investigate the possible variations on species dominance and biomass, and corresponding impact on the DMS $(\mathrm{P}, \mathrm{O})$ content.

\section{Material and methods}

\subsection{Field sampling}

Sampling was carried out on the RV Simon Stevin in 2016 and 2018 at 5 fixed stations chosen to cover a near-offshore gradient from station 700 (close to the Scheldt estuary) to the most marine station (ZG02) covering a major part of the BCZ (Fig. 1). The data from 2016 were published in Speeckaert et al. (2018). The samples were collected each month through the year and twice a month between March and May during the spring phytoplanktonic bloom. Seawater samples were collected at $3 \mathrm{~m}$ depth using $4 \mathrm{~L}$ Niskin bottles on a rosette sampler attached to a Conductivity-Temperature-Depth (CTD) probe (Seabird SBE25), for further analysis of Chl- $a$, DMS $(\mathrm{P}, \mathrm{O})$ concentrations and DNA extraction. The abiotic measurements at $3 \mathrm{~m}$ depth of SST, sea-surface salinity (SSS), suspended particulate matter (SPM), and nutrients concentrations were carried out by the Vlaams Instituut voor de Zee (VLIZ)

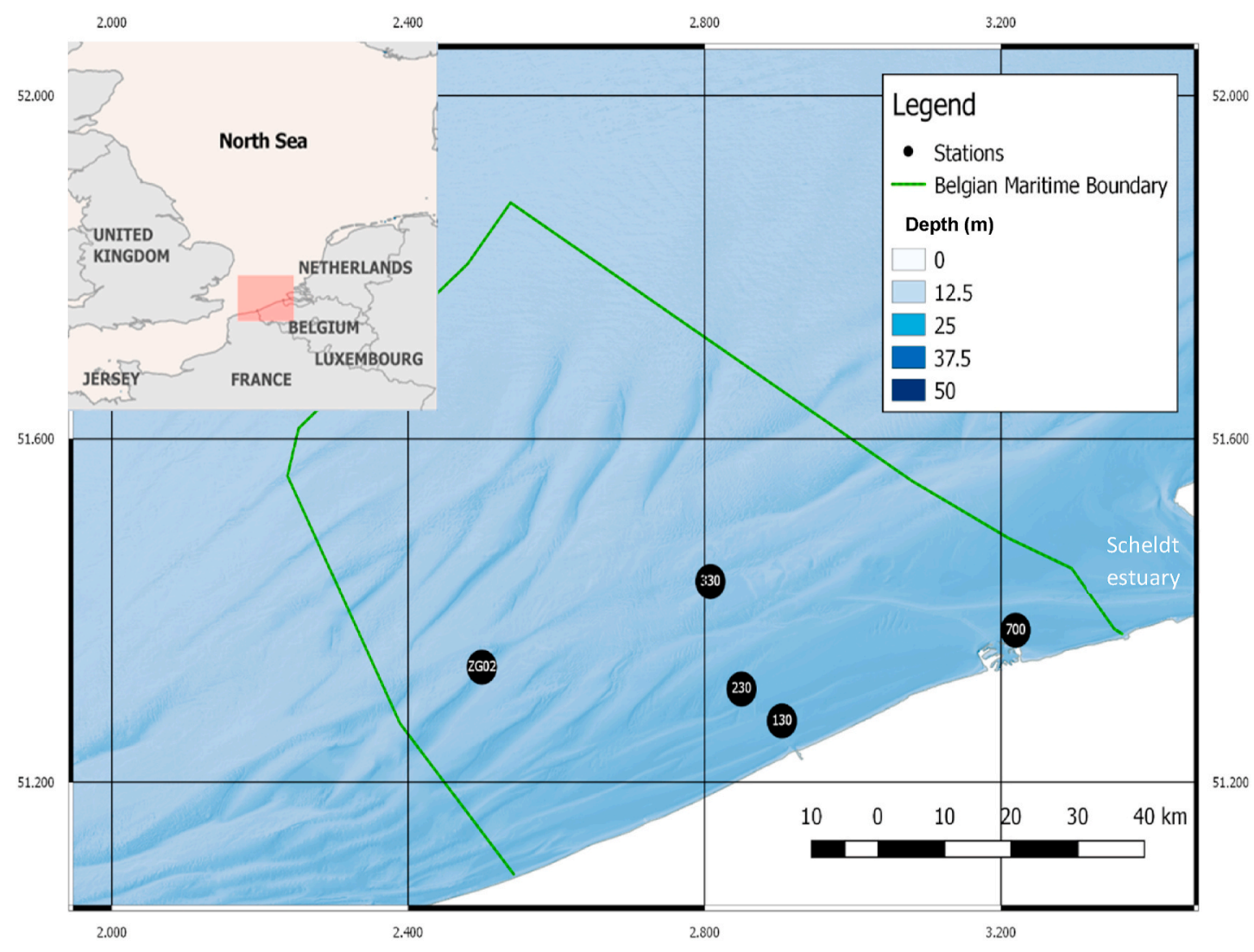

Fig. 1. Map of the sampling area with the five key stations (black circle) and the bathymetry (m) in the Belgian Coastal Zone (BCZ, North Sea). 
in the frame of the LifeWatch sampling campaigns (http://rshiny.lifewa tch.be/Station\%20data/) (Flanders Marine Institute, 2019) with the methodology found in Mortelmans et al. (2019). The daily global solar radiation data was collected at the Oostende station of the Royal Meteorological Institute of Belgium and allowed us to calculate the surface incident PAR.

\subsection{Chlorophyll-a}

A determined volume of the seawater collected was filtered on Whatman glass microfiber filters GF/F $25 \mathrm{~mm}$. The filters were immediately frozen and stored at $-20^{\circ} \mathrm{C}$ until analysis (within 1 month after sampling). Chl- $a\left(\mu \mathrm{g} \mathrm{L}^{-1}\right)$ was then extracted at $4{ }^{\circ} \mathrm{C}$ in $90 \%$ acetone (v:v) and measured fluorometrically using a Kontron Instruments SFM 25 (Strickland and Parsons, 1972).

\subsection{Phytoplankton diversity}

In 2016 and 2018, samples from station 330 were fixed with lugolgluteraldehyde ( $1 \% \mathrm{v}: \mathrm{v})$ and stored at $4{ }^{\circ} \mathrm{C}$ for species identification and cell density measurements by using inverted microscope. The station 330 is representative of the area (Rousseau et al., 2002). In 2018, DNA was sampled from March to December for the five stations. The DNA was collected by filtering seawater on $0.2 \mu \mathrm{m} 47 \mathrm{~mm}$ polycarbonate Durapore filters (Tynes, 2013). The filter was preserved at $-80^{\circ} \mathrm{C}$. DNA was extracted using DNeasy Plant Qiagen following manufacturer's protocol and libraries were prepared. 18S rDNA amplicon sequencing was performed using Illumina MiSeq sequencer which produced $2 \times 300$ bp paired-end sequences. Decomplexed sequences were analyzed using R software package phyloseq (McMurdie and Holmes, 2013) and the taxonomic annotation database used was Silva 1.32. The phytoplankton diversity was investigated based on several assumptions: (1) non-autotrophic kingdoms were removed; (2) as well as the unclassified genera by Silva; (3) Operational Taxonomic Units (OTUs) with same taxonomic annotations were merged; (4) singletons and genera not seen more than 3 times in at least $10 \%$ of the samples were eliminated; (5) the 50 most abundant genera were chosen to analyze the phytoplankton diversity over time.

The DMS(P,O):Chl- $a$ ratio were recalculated from published data
(Tables 1 and 2; Keller et al., 1989b; Townsend and Keller, 1996; Simó et al., 1998; Hatton and Wilson, 2007; Bucciarelli et al., 2013; Cooney, 2016; Cooney et al., 2019; Speeckaert et al., 2018; 2019; McParland and Levine, 2019; Royer et al. in review). The carbon per cell was calculated from cell volumes found in the literature or with the median cell volumes from Olenina (2006), and according to the formula given by Menden-Deuer and Lessard (2000). The biomass was converted to Chl- $a$ per cell assuming the C:Chl- $a$ ratio of $60 \mathrm{~g} \mathrm{~g}^{-1}$ (Geider, 1987).

\section{4. $\operatorname{DMS}(P, O)$ analysis}

The $60 \mathrm{~mL}$ borosilicate glass vials were acid-washed ( $\mathrm{HCl} 10 \%)$ and rinsed with high purity water obtained from a milli-Q system. The vials were covered with aluminum foil and baked at $350{ }^{\circ} \mathrm{C}$ for at least $1 \mathrm{~h}$ in a muffle furnace before the sampling (Kiene and Gerard, 1994). The 25 $\mathrm{mm}$ Whatman glass microfiber filters $\mathrm{GF} / \mathrm{F}$ were baked at $450{ }^{\circ} \mathrm{C}$ for $4 \mathrm{~h}$ (Kiene and Slezak, 2006). Intracellular DMS $(\mathrm{P}, \mathrm{O})\left(\mathrm{DMS}(\mathrm{P}, \mathrm{O})_{\mathrm{p}}\right)$ were obtained by the difference between $10 \mathrm{~mL}$ of unfiltered seawater samples (total DMS $(\mathrm{P}, \mathrm{O})\left(\mathrm{DMS}(\mathrm{P}, \mathrm{O})_{\mathrm{t}}\right)$ ) and dissolved DMS $(\mathrm{P}, \mathrm{O})(\mathrm{DMS}(\mathrm{P}$, $\left.\mathrm{O})_{d}\right)$. DMS $(\mathrm{P}, \mathrm{O})_{\mathrm{d}}$ was obtained by gentle filtration of $15 \mathrm{~mL}$ and only the first $10 \mathrm{~mL}$ filtrate was collected to avoid cell destruction at the end of the filtration that could release DMSP (Kiene and Slezak, 2006). All the samples were microwaved individually at $900 \mathrm{~W}$ till boiling $(\sim 15 \mathrm{sec})$ (Kinsey and Kieber, 2016) and then acidified with $5 \mu \mathrm{L} \mathrm{mL}^{-1}$ of $50 \%$ $\mathrm{H}_{2} \mathrm{SO}_{4}$ (Del Valle et al., 2011). The acid stopped the biological activity and preserved the DMSP (Curran et al., 1998). The acidification may produce rapid conversion of DMSP to DMS and presumably acrylate, inducing substantial losses of DMSP (Del Valle et al., 2011). But Kinsey and Kieber (2016) have recently observed that microwaving samples to boiling point are an alternative method for sample preservation prior to the addition of acid. The samples were crimped after cooling with gas-tight PFTE coated silicone septa and stored $24 \mathrm{~h}$ at dark before the refrigerator to allow the DMS to degas or oxidize (Kiene and Slezak, 2006).

The samples were sparged to remove the potential DMS left for 20 min. $5 \mathrm{~mL}$ of $12 \mathrm{M} \mathrm{NaOH}$ were added to the $10 \mathrm{~mL}$ samples to obtain a $\mathrm{pH}>12$ and quantitatively cleave DMSP into DMS for 24h (Dacey and Blough, 1987; Stefels, 2009). An Agilent 7890B gas chromatography with a purge and cryogenic trap system (Agilent column $30 \mathrm{~m}$ long, 0.32

Table 1

Ratio of particulate dimethylsulfonioproprionate $\left(\mathrm{DMSP}_{\mathrm{p}}\right)$ to Chlorophyll- $a$ (Chl- $a$ ) concentration (DMSP $\left.\mathrm{p}: \mathrm{Chl}-a\right)(\mathrm{mmol}: \mathrm{g})$, cell biovolume $\left(\mu \mathrm{m}^{3}\right)$, cell carbon (C) content ( $\mathrm{pgC}$ cell $^{-1}$ ) compiled from published literature for species found in the Belgian coastal zone (Fig. 1).

\begin{tabular}{|c|c|c|c|c|c|c|c|c|}
\hline Class & Genus & Species & $\begin{array}{l}\text { Biovolume } \\
\left(\mu \mathrm{m}^{3}\right)\end{array}$ & $\begin{array}{l}\mathrm{C}(\mathrm{pgC} \text { cell- } \\
\left.{ }^{1}\right)\end{array}$ & $\begin{array}{l}\text { Chl- } a \text { (pgChl- } a \text { cell }^{-} \\
\left.{ }^{1}\right)\end{array}$ & $\begin{array}{l}\operatorname{DMSP}_{\mathrm{p}}\left(\mathrm{fmol} \text { cell }^{-}\right. \\
\left.{ }^{1}\right)\end{array}$ & $\begin{array}{l}\text { DMSP }_{\mathrm{p}}: \text { Chl- } a \text { (mmol: } \\
\text { g) }\end{array}$ & $\begin{array}{l}\text { Data } \\
\text { from }\end{array}$ \\
\hline Diatom & Rhizosolenia & R. setigra & 69080.0 & 7561.5 & 126.0 & 112.5 & 0.9 & 1 \\
\hline Diatom & Guinardia & G. delicatula & 58139.0 & 2105.6 & 35.1 & & 1.9 & 2 \\
\hline Diatom & Thalassiosira & T. rotula & 15072.0 & 704.5 & 11.7 & 1.9 & $5.4 \pm 7.3$ & 1,2 \\
\hline Diatom & Thalassiosira & Thalassiosira sp. & 13713.0 & 652.5 & 10.9 & 40.8 & $3.2 \pm 0.8$ & 1,2 \\
\hline Diatom & Thalassiosira & T. pseudonana & 80.1 & 10.1 & & & $4.8^{-}$ & 3 \\
\hline Diatom & Rhizosolenia & Rhizosolenia sp. & 69080.0 & 2421.6 & 40.4 & 112.5 & 2.8 & 1 \\
\hline \multirow[t]{2}{*}{ Diatom } & $\begin{array}{l}\text { Pseudo- } \\
\text { Nitzschia }\end{array}$ & $\begin{array}{l}\text { Pseudo-Nitzschia } \\
\text { sp. }\end{array}$ & 120.0 & 14.0 & 0.2 & 0.2 & 0.9 & 1 \\
\hline & & & & & & Average \pm s.d. : & $3.2 \pm 3.1$ & \\
\hline Dinoflagellates & Heterocapsa & H. rotundata & 234.0 & 66.3 & 1.1 & 20.8 & $18.7 \pm 0.9$ & 4,5 \\
\hline Dinoflagellates & Gyrodinium & G. aureolum & 5007.6 & 814.3 & 13.6 & 5.3 & 0.4 & 1 \\
\hline Dinoflagellates & Katodinium & Katodinium sp. & 1439.0 & 293.3 & 4.9 & 201.2 & 41.2 & 6 \\
\hline Dinoflagellates & Karlodinium & K. veneficum & 739.0 & 106.7 & 1.8 & 7.0 & 3.9 & 1 \\
\hline Dinoflagellates & Gymnodinium & G. simplex & 265.0 & 73.4 & 1.2 & 238.5 & 195.1 & 1 \\
\hline \multirow[t]{2}{*}{ Dinoflagellates } & Tripos & T. fusus & 19500.0 & 2479.4 & 41.3 & 2.8 & 0.1 & 7 \\
\hline & & & & & & Average \pm s.d. : & $37.1 \pm 65.3$ & \\
\hline Prymnesiophyceae & Phaeocystis & P. globosa & 75.0 & 12.4 & 0.2 & 16.3 & $82.3 \pm 11.5$ & $3,2,8$ \\
\hline \multirow[t]{2}{*}{ Prymnesiophyceae } & Phaeocystis & Phaeocystis sp. & 46.6 & 8.0 & & & 59.0 & 1 \\
\hline & & & & & & Average \pm s.d. : & $76.5 \pm 15.0$ & \\
\hline
\end{tabular}

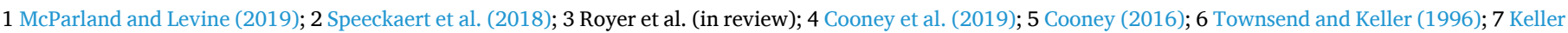
et al. (1989)b; 8 Speeckaert et al. (2019). 
Table 2

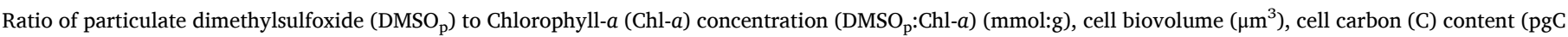
$\mathrm{cell}^{-1}$ ) compiled from published literature for species found in the Belgian coastal zone (Fig. 1).

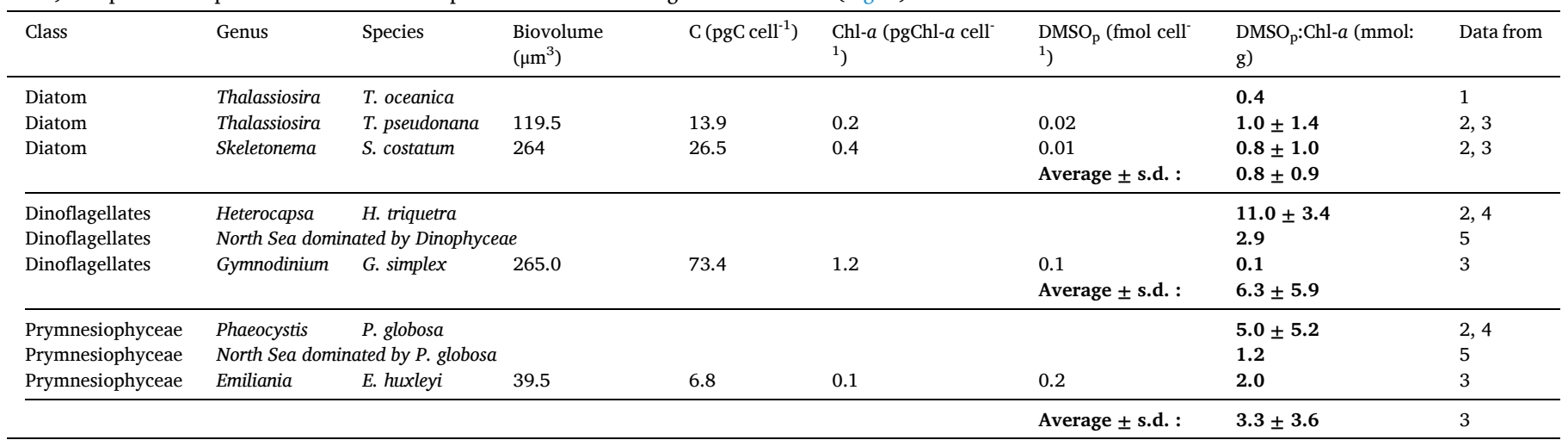

1 Bucciarelli et al. (2013); 2. Royer et al. (in review); 3 Hatton and Wilson (2007); 4 Speeckaert et al. (2019); 5 Simó et al. (1998).

mm internal diameter, $0.25 \mu \mathrm{m}$ film thickness) was applied to analyze the DMS released. The GC was equipped with sulfur selective Flame Photometric Detector (FPD) and the carrier gas was $\mathrm{He}\left(2 \mathrm{ml} \mathrm{min}^{-1}\right)$. The FPD was kept at $350{ }^{\circ} \mathrm{C}$ with a $\mathrm{H}_{2}$ flow of $72 \mathrm{ml} \mathrm{min}^{-1}$, a synthetic air flow of $72 \mathrm{ml} \mathrm{min}^{-1}$ and a makeup $\left(\mathrm{N}_{2}\right)$ flow of $20 \mathrm{ml} \mathrm{min}^{-1}$. The capillary column was kept at $60^{\circ} \mathrm{C}$. DMS was quantitatively purged from the vial by the He flow carried through a long stainless-steel needle inserted through the septum into the liquid phase and during $20 \mathrm{~min}$. The DMS flew through two Dewar maintained cold around $-30{ }^{\circ} \mathrm{C}$ with liquid nitrogen to trap residual water vapor (Andreae and Barnard, 1984). The DMS is then trapped in a PFTE loop immersed in liquid nitrogen $\left(-196^{\circ} \mathrm{C}\right)$. At the end of the purge, the loop was transferred in boiling water and the DMS is injected in the GC.

For the DMSO analysis, $5 \mathrm{~mL} \mathrm{HCl} \mathrm{37 \%} \mathrm{(HCl} \mathrm{37 \%} \mathrm{Normapur,} \mathrm{VWR)}$ and $1 \mathrm{~mL} \mathrm{TiCl}_{3}$ (30\%, Merck) (Kiene and Gerard, 1994; Deschaseaux et al., 2014) were added into the precedent vial yet analyzed. Even if we consider the reaction efficiency $<100 \%$, it will not interfere with the analysis since the system is calibrated against DMSO standards, assuming the same reduction efficiency for both standards and samples (Champenois and Borges, 2019). After $48 \mathrm{~h}$ at room temperature, $3 \mathrm{~mL}$ of $12 \mathrm{M} \mathrm{NaOH}$ were added to avoid injecting acid fumes into the GC (Kiene and Gerard, 1994). The DMS produced from the reduction of DMSO was analyzed as described previously. The DMS $(\mathrm{P}, \mathrm{O})$ quantified in arrow in the same sample was validated by Champenois and Borges (2019). The same procedure was applied for the calibration. The DMSP used was obtained from Research Plus and the DMSO from 99.9\% pure stock solution (Merck). Working solutions were prepared with the successive dilution in MilliQ water but DMSP and DMSO were diluted in the same vial. Calibration curves were made weekly to ensure the GC stability for the detector by fitting a quadratic curve for the FPD. The average precision was 5 and $8 \%$ for DMSP and DMSO calibration, respectively. Any leaks during the analysis were detected by using a Thermo Scientific GLD Pro Gas Leak Detector every day.

\subsection{Statistical analysis}

The statistical comparison of the variables between the two years was performed using the parametric paired-samples Student t-test. The assumption of normality was checked using the Shapiro-Wilk test and the Q-Q plot. In case of deviation of the normality ( $<0.05$ ), the Wilcoxon t-test was applied. To investigate the correlation between the variables, the Pearson's $r$ coefficient and its $p$ value was used. In case of deviation of normality by the Shapiro-Wilk test $(\mathrm{p}<0.05)$ and the Q-Q plot, the non-parametric Spearman's $\rho$ coefficient was applied.

The Kaiser-Meyer-Olkin index ( $>0.50$ ) and Bartlett sphericity test ( $\mathrm{p}$ $<0.05$ ) were used to ensure the application of Principal Component Analysis (PCA) for which we assumed the application of an Oblimin rotation. The principal components (PCs) have to explain at least $50 \%$ of the total percentage of variance between all the variables. The loading component (LC) explaining the correlation between the PC and the variable was considered significant when $\geq \pm 0.60$. These statistics were realized using the IBM SPSS Statistics software (version 23.0.0.0) and the assumptions were based on Goss-Sampson (2018).

\section{Results and discussion}

The years 2016 and 2018 were characterized by the typical phytoplankton succession for the area (Rousseau et al., 2002) with an early spring diatom bloom followed by a huge Phaeocystis globosa (here after Phaeocystis) bloom. Yet, in early spring, Chl- $a$ concentrations for the coastal stations were higher in 2018 than 2016. A summer diatom bloom was also observed during both years, with higher Chl- $a$ concentrations in 2018 compared to 2016 .

\subsection{Spring phytoplankton bloom}

As previously described in the BCZ (Rousseau et al., 2002), the Phaeocystis bloom occurred at the end of April both in 2016 and 2018. The values were not significantly different between the two years with an average Chl- $a$ concentration of $13.6 \pm 6.0 \mu \mathrm{g} \mathrm{L}^{-1}$ and $15.7 \pm 7.8 \mu \mathrm{g} \mathrm{L}^{-1}$ in 2016 and 2018 respectively ( $\mathrm{p}=0.653$ ) (Fig. 2).

However, both years differed significantly with respect to the early spring bloom of diatoms occurring during the month of March in 2016,

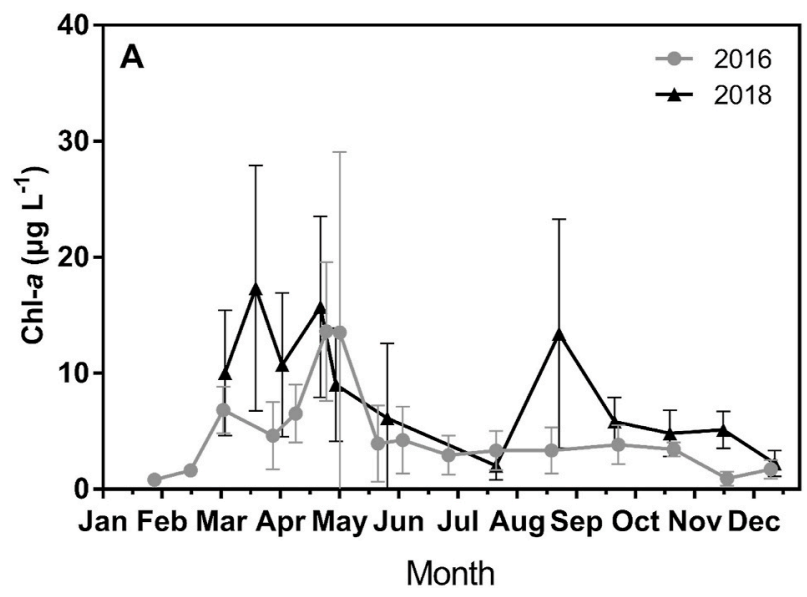

Fig. 2. Seasonal evolution of average ( \pm standard deviation) Chlorophyll- $a$ (Chl-a) concentration ( $\mu \mathrm{g} \mathrm{L}^{-1}$ ) for the five stations sampled in the Belgian coastal zone in 2016 and 2018. Location of the sampling stations are shown in Fig. 1. 
and from the first days of March until early April in 2018 (5.6 \pm 2.6 and $12.8 \pm 8.0 \mu \mathrm{g} \mathrm{L}^{-1}$ respectively; $\mathrm{p}<0.05$ ) (Fig. 2). The higher Chl- $a$ values were due to the Chl- $a$ concentrations from the coastal stations $(700,130$, and 230) (Fig. 3a and b) with an average Chl- $a$ at these three stations and for the diatom bloom period of $6.9 \pm 1.9$ and $16.7 \pm 7.5 \mu \mathrm{g} \mathrm{L}^{-1}$ for 2016 and 2018 respectively ( $\mathrm{p}=0.073$ ).

We tested if differences in light intensity, SST and nutrient concentrations might be responsible of the earlier and higher diatom spring bloom in 2018 compared to 2016 . The light availability is the primary control on spring phytoplankton onset in the North Sea (Wiltshire et al., 2008) and depends on the combination of incoming solar radiation and the SPM content that attenuates light penetration. During the early diatom bloom, SPM for the coastal stations was significantly higher in $2018\left(173.3 \pm 32.1 \mathrm{mg} \mathrm{L}^{-1}\right)$ than $2016\left(48.7 \pm 53.2 \mathrm{mg} \mathrm{L}^{-1}\right)(\mathrm{p}<0.01)$ (Fig. 3i and j). However, the incident light was more favorable in 2018 and allowed an earlier onset of the diatom bloom (Rousseau, 2000) (Pearson's correlation between Chl- $a$ and incident light, $\mathrm{p}<0.05$ ). The incoming PAR was indeed 1.5 times higher in February 2018 than 2016 $\left(204.2 \pm 85.9\right.$ and $137.6 \pm 81.6 \mu \mathrm{E} \mathrm{m}^{-2} \mathrm{~s}^{-1}$ respectively; $\left.\mathrm{p}<0.001\right)$ (Fig. 3o)

SST for the coastal stations was less favorable for the diatom growth (Montagnes and Franklin, 2001) in February $2018\left(5.3 \pm 0.5^{\circ} \mathrm{C}\right)$ than in $2016\left(6.5 \pm 0.2{ }^{\circ} \mathrm{C}\right)(\mathrm{p}<0.05)$ and during the bloom in $2018(4.2 \pm$ $\left.2.2^{\circ} \mathrm{C}\right)$ than $2016\left(7.6 \pm 1.0^{\circ} \mathrm{C}\right)(\mathrm{p}=0.063)$ (Fig. $\left.3 \mathrm{~m}, \mathrm{n}\right)$. The SST in winter 2018 was the lowest during the last 13 years (Borges et al., 2019). Nevertheless, lower temperature during winter-spring bloom period might induce higher phytoplankton biomass resulting from a lower grazing rate of the zooplankton (Sommers and Lewandowska, 2011).

In addition, we observed a higher nutrient supply coming from the
Scheldt estuary during the early blooming period with SSS lower in 2018 than in 2016 (30.9 \pm 1.3 and $32.9 \pm 1.8$ respectively; $p=0.086)$ (Fig. $3 c$ and d). The DIN concentration was higher in 2018 than in 2016 with respectively $45.8 \pm 9.6$ and $19.6 \pm 17.9 \mu \mathrm{mol} \mathrm{L}^{-1}(\mathrm{p}=0.084$ ) (Fig. $3 \mathrm{k}$ and $\mathrm{l}$ ) and $\mathrm{PO}_{4}$ concentration was significantly differentiated with $0.6 \pm$ 0.2 and $0.2 \pm 0.2 \mu \mathrm{mol} \mathrm{L}^{-1}(\mathrm{p}<0.05)$ (Fig. $3 \mathrm{~g}$ and $\left.\mathrm{h}\right)$. The DSi concentration was not significantly different even if we also observed higher values with $16.3 \pm 4.7$ in 2018 and $4.3 \pm 5.1 \mu \mathrm{mol} \mathrm{L} \mathrm{L}^{-1}$ in $2016(\mathrm{p}=$ 0.250) (Fig. 3e and f).

In conclusion, the timing of the early spring diatom bloom in 2018 compared to 2016 seems to be the result of better light conditions in late winter. Furthermore, the higher biomass observed during the blooming period might be the consequence of higher nutrient concentrations and possibly lower zooplankton grazing resulting from lower SST.

The relative cellular density (\%) was analyzed in 2016 and 2018 for the station 330, representative for the BCZ area (Rousseau et al., 2002). For March 2016, diatoms represented $\sim 40 \%$ and P. globosa $\sim 60 \%$ (Fig. 4). In April 2016, the relative abundance of the Prymnesiophyceae increased up to $96 \%$ while the diatoms decreased to $4 \%$ (Fig. 4). At the beginning of May 2016, P. globosa still represented 99\% while only 1\% of diatoms characterized the phytoplankton community (Fig. 4). In May 2018 , the phytoplankton community was represented by $94 \%$ of P. globosa and 3\% of diatoms (Fig. 4). The dinoflagellates were for both years almost absent for this period $(<0.2 \%)$. With genomic data, we can additionally explore the phytoplankton composition during the early spring bloom for the station 330 . The diatom community was mainly composed by the genus Thalassiosira, including T. rotula, T. tenera and T. lundiana, as well as Guinardia delicatula, Rhizosolenia shubsholei and Minutocellus polymorphus. Some diatom genera from 2016 were not
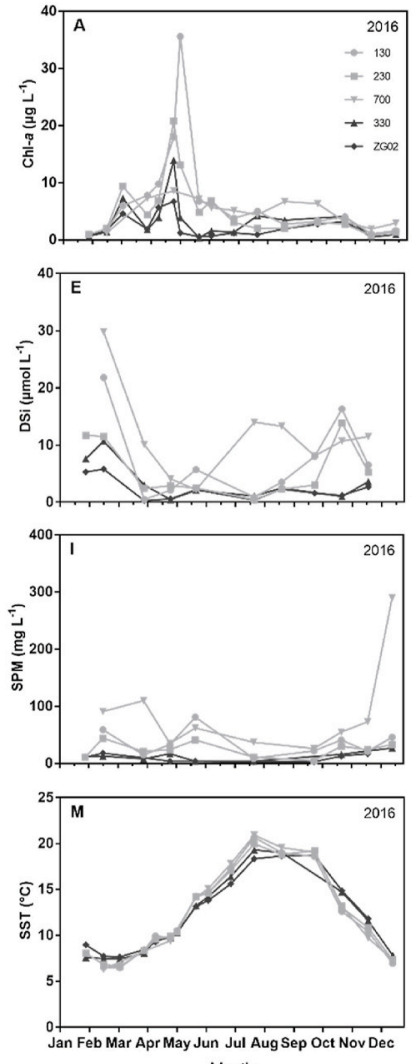

Month
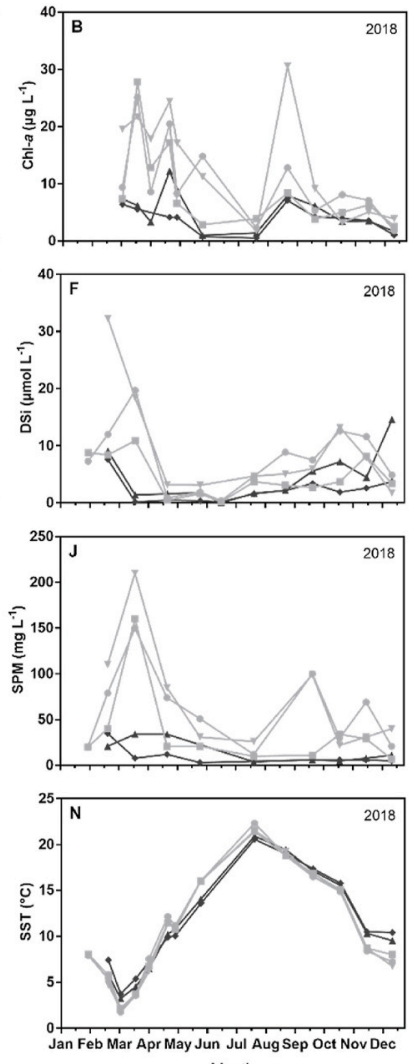

Month
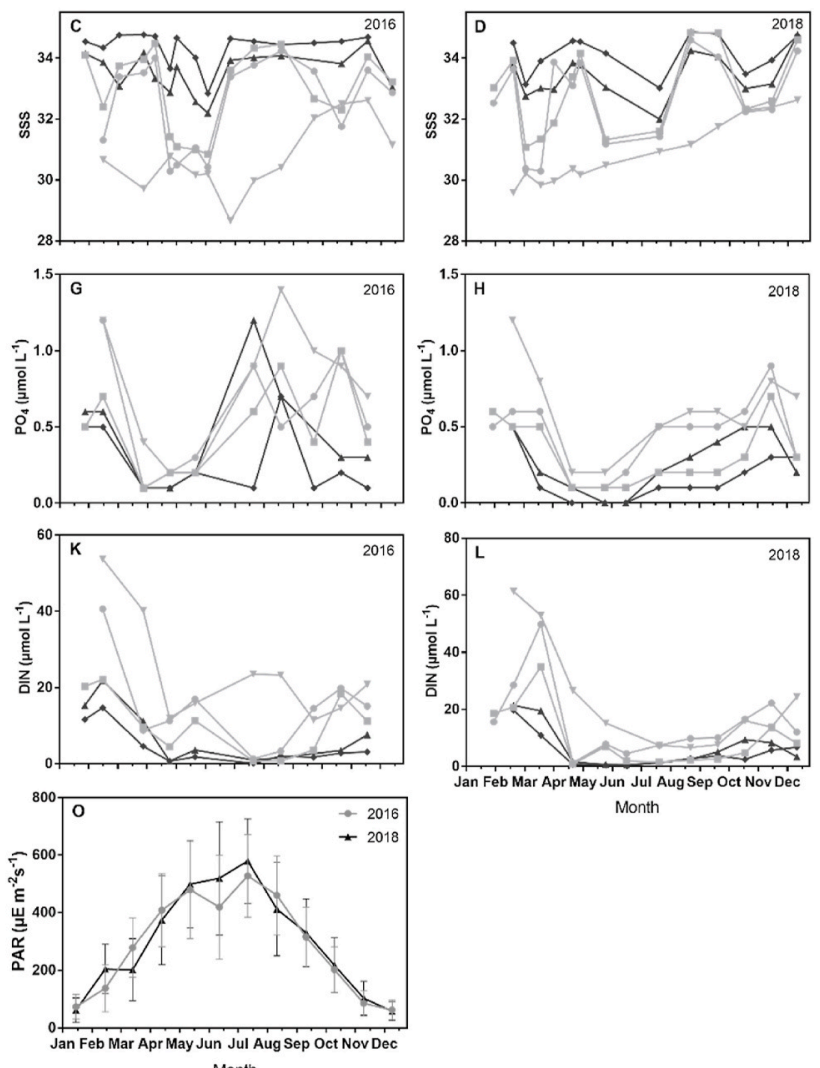

Month

Fig. 3. Seasonal and spatial evolution of (a) Chlorophyll- $a$ (Chl-a) concentration ( $\mu \mathrm{L} \mathrm{L}^{-1}$ ) in 2016, (b) in 2018; (c) Sea Surface Salinity (SSS) in 2016, (d) in 2018; (e) Dissolved Silica (DSi) concentration $\left(\mu \mathrm{mol} \mathrm{L}^{-1}\right)$ in 2016, (f) in 2018; (g) phosphate $\left(\mathrm{PO}_{4}\right)$ concentrations $\left(\mu \mathrm{mol} \mathrm{L}^{-1}\right)$ in 2016, (h) in 2018; (i) Suspended Particulate Matter (SPM) (mg L $\left.\mathrm{m}^{-1}\right)$ in 2016, (j) in 2018; (k) Dissolved Inorganic Nitrogen (DIN) concentration ( $\mu \mathrm{mol} \mathrm{L}^{-1}$ ) in 2016, (l) in 2018; (m) Sea Surface Temperature (SST) $\left({ }^{\circ} \mathrm{C}\right)$ in 2016, (n) in 2018; and (o) seasonal evolution of daily averaged Photosynthetic Active Radiation (PAR) $\left(\mu \mathrm{E} \mathrm{m}^{-2} \mathrm{~s}^{-1}\right)$ for the five stations sampled in the Belgian coastal zone in 2016 and 2018 (Fig. 1). 


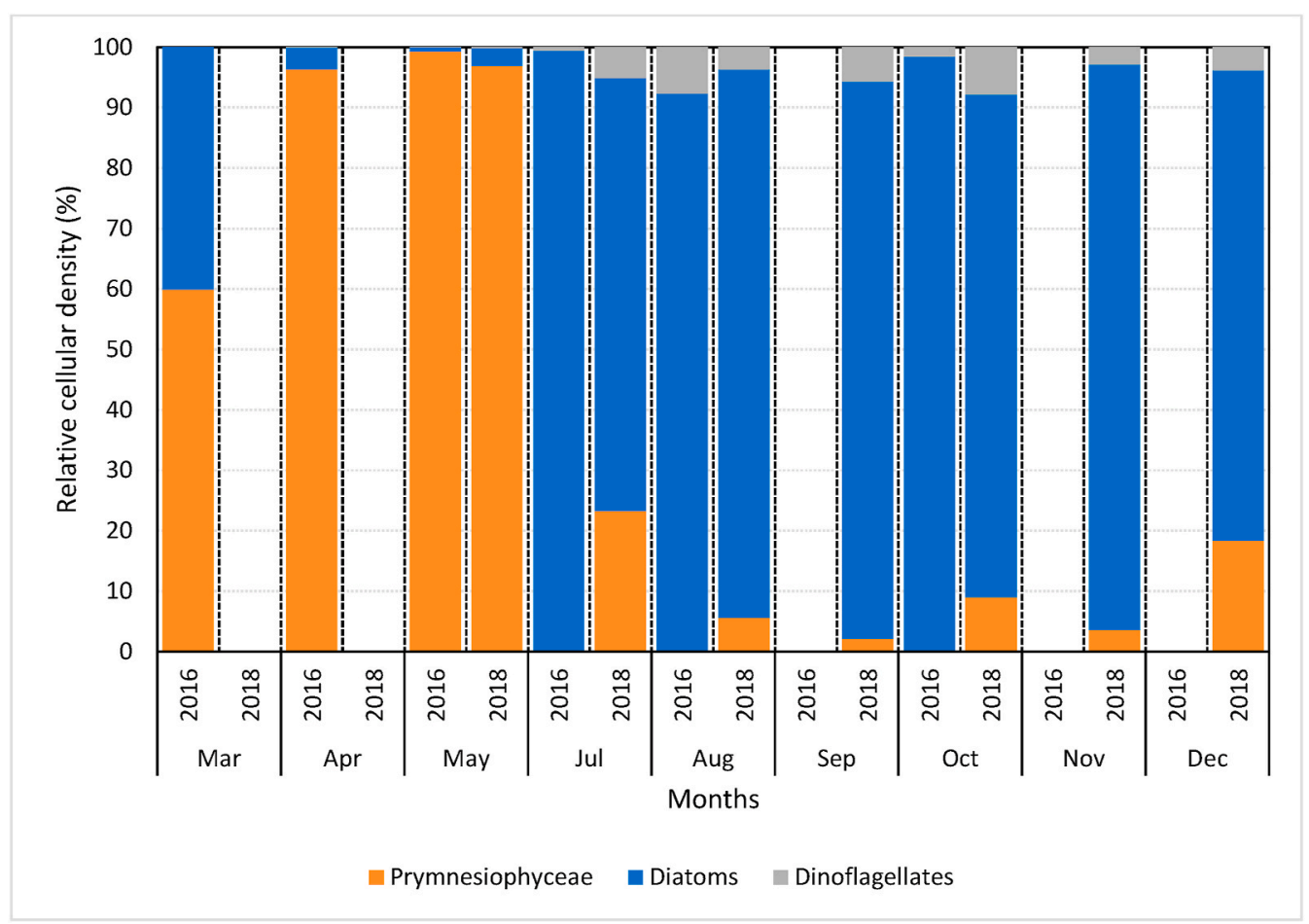

Fig. 4. Seasonal evolution of the relative cellular density (\%) for the station 330 in the Belgian coastal zone (Fig. 1) analyzed for the phytoplankton diversity from March to October in 2016 and from March to December in 2018 with distinction between the Prymnesiophyceae, diatoms and dinoflagellates.

observed in 2018 such as Asterionella, Coscinodiscus, Thalassionema, Biddulphia and Nitzschia. The dinoflagellates observed were the species Heterocapsa rotundata and Karlodinium veneficum. Other species such as Gyrodinium aureolum, G. spirale, Sinophysis sp., Tripos fusus, Katodinium glaucum, or Warnowia sp. among others were also detected.

\subsection{Summer phytoplankton bloom}

The Chl- $a$ concentrations in August (Fig. 2) were also different between 2016 and $2018(\mathrm{p}=0.090)$. The concentration was 4.1 times higher in $2018\left(13.4 \pm 9.9 \mu \mathrm{g} \mathrm{L}^{-1}\right)$ than in $2016\left(3.4 \pm 2.0 \mu \mathrm{g} \mathrm{L}^{-1}\right)$. The PAR was 1.2 times higher in June 2018 than in 2016 ( $<<0.05$ ) (Fig. 3o). This explains the significant higher average SST for all the stations observed in July 2018 compared to $2016\left(21.3 \pm 0.7^{\circ} \mathrm{C}\right.$ and $19.8 \pm$ $1.0{ }^{\circ} \mathrm{C}$ respectively; $\mathrm{p}<0.01$ ), in response to a large-scale heatwave in Europe (Magnusson et al., 2018; Borges et al., 2019). As a matter of fact, the temperature was significantly higher at the coastal stations in 2018 than in 2016 from late April to July ( $<<0.05$ ) (Fig. 3m, n). Temperature is one of the most important drivers of the phytoplankton community composition (Schabhüttl et al., 2013; Striebel et al., 2016; Hunter-Cevera et al., 2016), and the higher biomass results from higher cell division rates in warmer conditions (Richardson and Schoeman 2004; Hunter-Cevera et al., 2016).

In July 2016, the community was dominated by diatoms (99\%) with a small increase of dinoflagellates (1\%) (Fig. 4). In 2018, the diatoms represented $72 \%$ with $23 \%$ of Prymnesiophyceae and $5 \%$ of dinoflagellates (Fig. 4). During August 2016, diatoms still dominated the community (92\%) with a slight increase of dinoflagellate (8\%) (Fig. 4). Diatoms represented up to $91 \%$ in August 2018 while Prymnesiophyceae and dinoflagellates were represented by 6 and 4\%, respectively (Fig. 4b). October was the last month sampled in 2016 for the phytoplankton diversity characterized with $98 \%$ and $2 \%$ of diatoms and dinoflagellates, respectively (Fig. 4a). From September to December 2018, the community was composed by $87 \pm 8,8 \pm 7$ and $5 \pm 2 \%$ of diatoms, Prymnesiophyceae and dinoflagellates, respectively. Diatom community in August 2018 was mainly composed by Thalassiosira sp. (T. rotula, T. tenera and T. lundiana), M. polymorphus, G. delicatula and Chaetoceros socialis. The dinoflagellate community was still characterized by H. rotundata while some unclassified Syndiniales, Gyrodinium sp., G. aureolum, G. spirale, T. fusus, Lepidodinium sp., Warnowia sp., K. glaucum and Sinophysis $s p$ were observed. From September to December 2018, Thalassiosira sp., M. polymorphus, G. delicatula still represented the diatom community while the presence of the dinoflagellates $H$. rotundata, K. veneficum, Gyrodinium sp or Syndiniales $s p$. was detected.

\subsection{Spatial and seasonal variations of $D M S(P, O)$ concentrations}

While the annual average Chl- $a$ was significatively higher in 2018 $\left(8.5 \pm 7.2 \mu \mathrm{g} \mathrm{L}^{-1}\right)$ than in $2016\left(5.1 \pm 5.5 \mu \mathrm{g} \mathrm{L}^{-1}\right)(\mathrm{p}<0.001)$, the annual average DMSP ${ }_{\mathrm{p}}$ concentration between the two years was similar $(162$ $\pm 246 \mathrm{nmol} \mathrm{L}^{-1}$ in 2018 and $207 \pm 374 \mathrm{nmol} \mathrm{L}^{-1}$ in 2016; $\left.\mathrm{p}=0.438\right)$. Even if there was slight difference in DMSP $_{\mathrm{p}}$ in early may (448 \pm 183 in 2018 and $1142 \pm 487 \mathrm{nmol} \mathrm{L}^{-1}$ in 2016), no significant difference was observed ( $\mathrm{p}=0.086$ ) (Fig. $5 \mathrm{a}$ ) and the Chl- $a$ concentration was similar ( $p=0.752$ ) (Fig. 2). Despite a higher biomass in August 2018 than 2016, there was no difference in DMSP $_{\mathrm{p}}$ concentrations during both years, with a low value of $49 \pm 20$ and $54 \pm 14 \mathrm{nmol} \mathrm{L}^{-1}$ in 2016 and 2018, respectively $(\mathrm{p}=0.732)$. Even if the Chl- $a$ concentrations were different between the two years during both the early spring and summer blooms, the similarities in $\mathrm{DMSP}_{\mathrm{p}}$ concentrations could be explained by the phytoplankton composition. The early spring bloom was mainly characterized by low-DMSP producers such as the diatom Thalassiosira $s p$. and the dinoflagellates $H$. rotundata and $K$. veneficum (Table 1 ). The same conclusion was observed during summer with the diatoms Thalassiosira sp. and M. polymorphus, or the dinoflagellates $H$. rotundata, Gyrodinium sp. and Syndiniales sp. (Table 1).

The seasonal pattern of $\mathrm{DMSO}_{\mathrm{t}}$ concentration was similar between both years (Fig. 5 b) but the yearly mean was significantly different ( 88 \pm 107 and $48 \pm 68 \mathrm{nmol} \mathrm{L}^{-1}$ in 2016 and 2018 respectively; $\mathrm{p}<0.01$ ). The average value of $\mathrm{DMSO}_{\mathrm{t}}$ during the Phaeocystis bloom was $246 \pm$ 205 and $163 \pm 193 \mathrm{nmol} \mathrm{L}^{-1}$ for 2016 and 2018, respectively ( $\mathrm{p}=0.597$ ) (Fig. 5b). Significant difference was only observed at the beginning of 

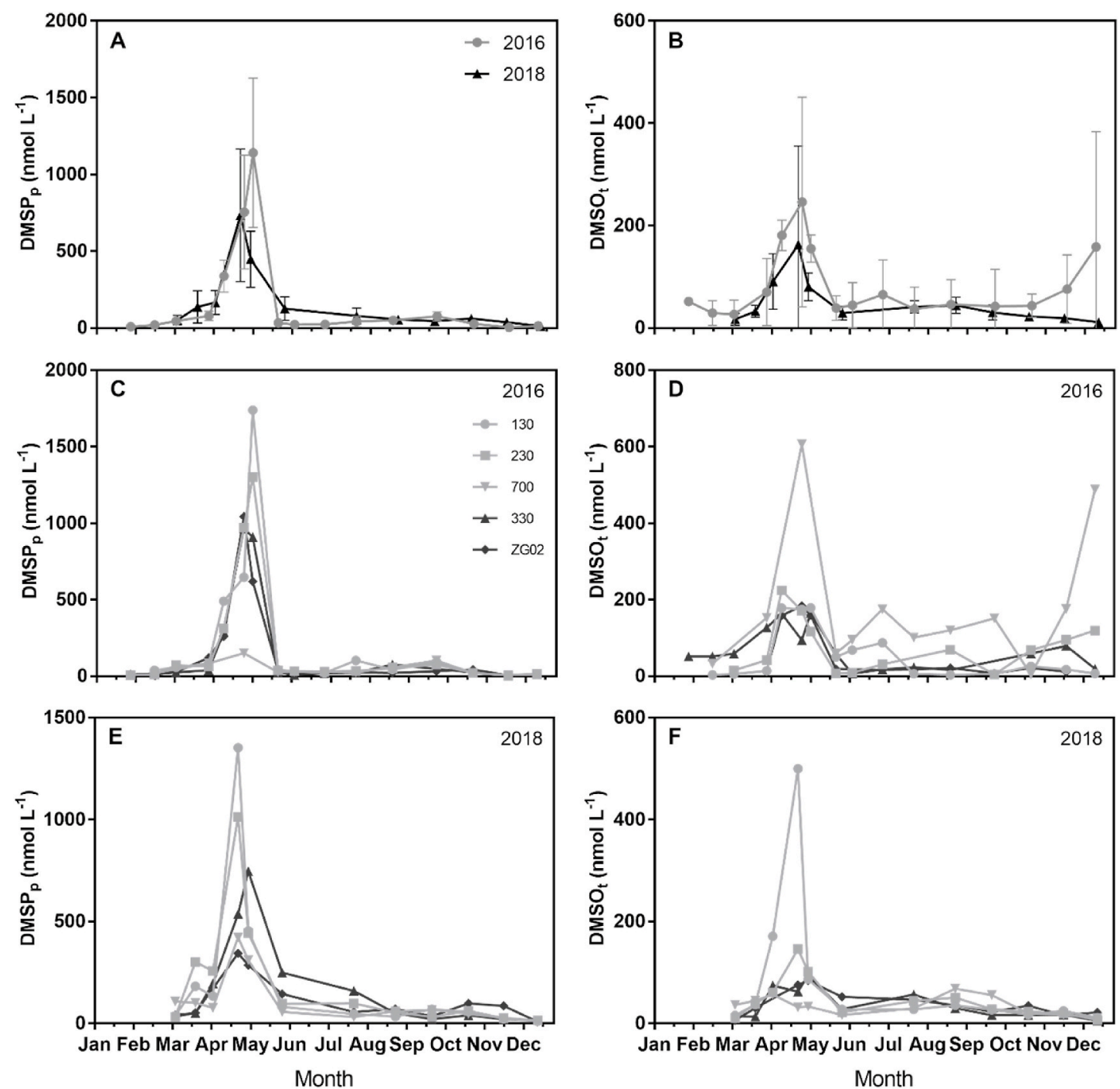

Fig. 5. Seasonal evolution in 2016 and 2018 of average ( \pm standard deviation) (a) particulate dimethylsulfonioproprionate (DMSP $\left.\mathrm{p}_{\mathrm{p}}\right)\left(\mathrm{nmol} \mathrm{L}^{-1}\right)$; (b) total dimethylsulfoxide (DMSO $)\left(\mathrm{nmol} \mathrm{L}^{-1}\right)$; and seasonal and spatial evolution of (c) DMSP $\mathrm{p}_{\mathrm{p}}\left(\mathrm{nmol} \mathrm{L}^{-1}\right)$ and (d) $\mathrm{DMSO}_{\mathrm{t}}\left(\mathrm{nmol} \mathrm{L}^{-1}\right){\text { in } 2016 \text {; (e) } \text { DMSP }_{\mathrm{p}}\left(\mathrm{nmol} \mathrm{L}^{-1}\right) \text { and (f) DMSO }}_{\mathrm{t}}$ $\left(\mathrm{nmol} \mathrm{L}{ }^{-1}\right.$ ) in 2018 for the five stations sampled in the Belgian coastal zone (Fig. 1).

May, as it was for the $\mathrm{DMSP}_{\mathrm{p}}$, with concentration 1.9 times higher in 2016 than in 2018 ( $<<0.05$ ). In $2018, \mathrm{DMSO}_{\mathrm{p}}$ represents $66 \%$ of the $\mathrm{DMSO}_{\mathrm{t}}$ pool and showed a similar seasonal evolution (Fig. 6a). $\mathrm{DMSO}_{\mathrm{d}}$ was generally lower than $\mathrm{DMSO}_{\mathrm{p}}$ and presented a different seasonal pattern since the peak of $\mathrm{DMSO}_{\mathrm{d}}$ occurred just before the $\mathrm{DMSO}_{\mathrm{p}}$ peak in late April (Fig. 6a and b).

The spatial variations (coastal-offshore) observed for Chl- $a$ (Fig. 3a) also occurred for $\mathrm{DMSP}_{\mathrm{p}}$ in 2016 but the $\mathrm{DMSO}_{\mathrm{t}}$ concentrations did not clearly differ among the stations, except for station 700 (Fig. 5c and d). The high concentration observed at station 700 was related to the high SPM concentration and linked to the resuspension of sediment (Speeckaert et al., 2018). In 2018, the $\mathrm{DMSP}_{\mathrm{p}}$ concentration was associated with the Phaeocystis bloom with a nearshore-offshore gradient and concentrations from 536 to $1353 \mathrm{nmol} \mathrm{L}^{-1}$ (Fig. 5e). This gradient did not occur in late May nor during the summer. $\mathrm{DMSO}_{\mathrm{t}}$ and $\mathrm{DMSO}_{\mathrm{p}}$ in 2018 showed a seasonal pattern with the same gradient during the Phaeocystis bloom with values varying from 62 to $500 \mathrm{nmol} \mathrm{L}^{-1}$ (Fig. 5f) and from 33 to $498 \mathrm{nmol} \mathrm{L}^{-1}$ (Fig. 6c), respectively. The distinction between coastal and offshore stations for the $\mathrm{DMSO}_{d}$ variations was no longer clearly identified (Fig. 6d). Following the Chl-a peak during August 2018 for station 700 (Fig. 3b), the $\mathrm{DMSO}_{\mathrm{t}}$ and the $\mathrm{DMSO}_{\mathrm{p}}$ concentration reached a value of 69 and $59 \mathrm{nmol} \mathrm{L}^{-1}$ respectively, which were the highest concentrations observed for this period (Figs. $5 \mathrm{f}$ and $6 c)$.

\section{4. $D M S(P, O)$ relations and $D M S O_{p}: D M S P_{p}$ ratio}

We further explored the similarities between all the variables in 2016 and 2018 by PCA. The Fig. 7a shows the grouping of variables within an orthogonal 2D-space along the two most relevant PCs explaining $57.8 \%$ of the total variance $(\mathrm{n}=86)$. $\mathrm{DMSP}_{\mathrm{p}}, \mathrm{DMSO}_{\mathrm{t}}$ and Chl- $a$ explained more than $69.2 \%$ of variation along the PC2. With only the 2016 data (Fig. $7 \mathrm{~b}$; $\mathrm{n}=41$ ), two PCs characterized $61.7 \%$ of the variance where the variables were clustering together as previously $(>67.3 \%)$. With only the 2018 data (Fig. $7 \mathrm{c} ; \mathrm{n}=45$ ), $61.6 \%$ of the variance were explained by two PCs where $\mathrm{DMSP}_{\mathrm{p}}$ and $\mathrm{DMSO}_{\mathrm{p}}$ correlated (>84.7\%). The combining 2016-2018 PC analysis brings statistical support for the link between the Chl- $a$ and the DMS $(\mathrm{P}, \mathrm{O})$ that are varying together. The previous observation was not noticed for the data in 2018 since the DMS $(\mathrm{P}, \mathrm{O})_{\mathrm{p}}$ were not clustered with Chl- $a$. The Spearman correlation analysis followed the same information with significant non-parametric correlation between DMSP ${ }_{\mathrm{p}}$ and Chl- $a(\rho=0.62 ; \mathrm{p}<0.01)$ with data from 2016 and 2018. More precisely, $\mathrm{DMSP}_{\mathrm{p}}$ and Chl- $a$ were highly correlated in 2016 ( $\rho=0.71 ; \mathrm{p}<0.001)$ but to a lesser extent in $2018(\rho=0.42 ; \mathrm{p}<0.001)$ 

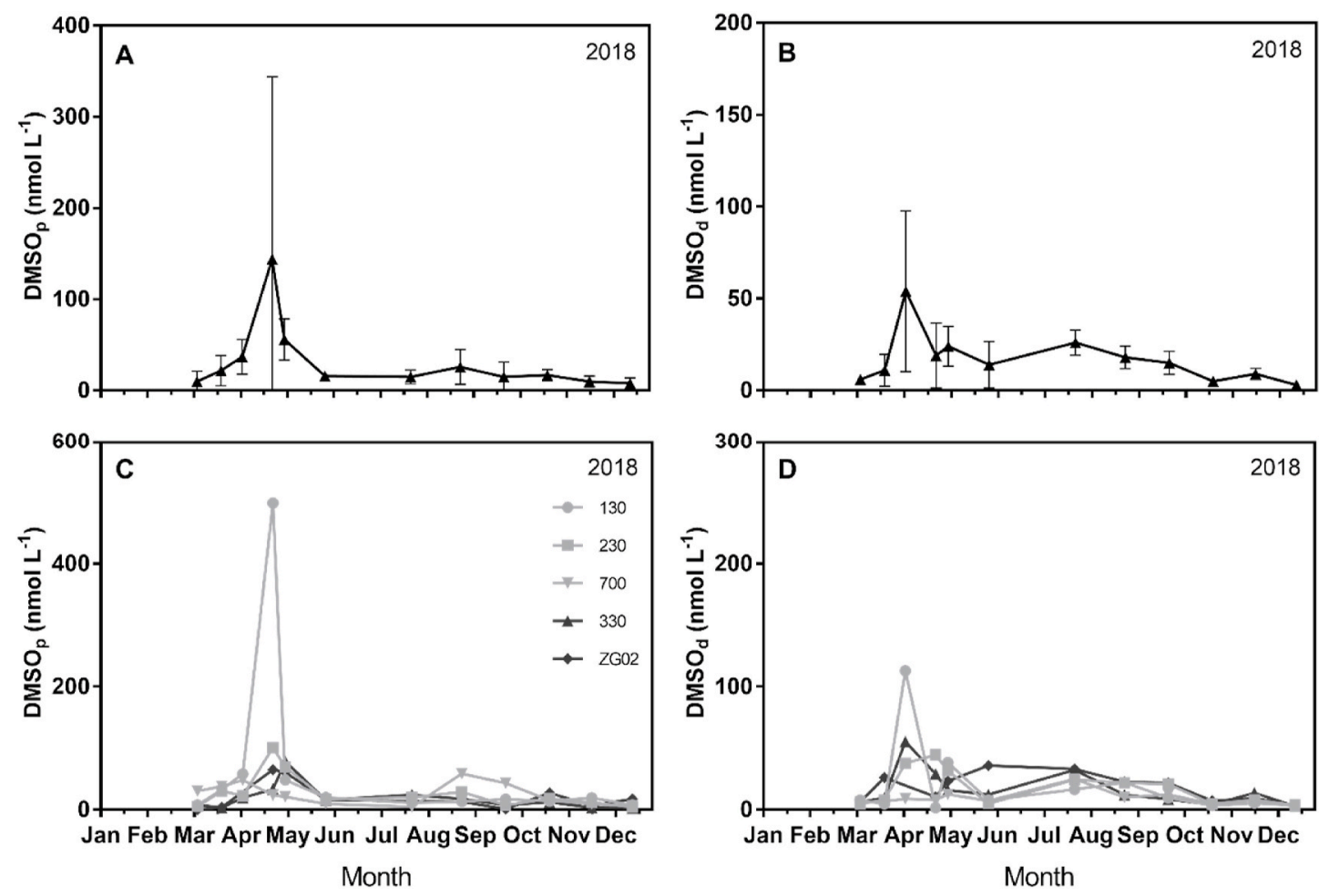

Fig. 6. Seasonal evolution of average ( \pm standard deviation) (a) particulate dimethylsulfoxide $\left(\mathrm{DMSO}_{\mathrm{p}}\right)\left(\mathrm{nmol} \mathrm{L}^{-1}\right)$, (b) dissolved dimethylsulfoxide (DMSO $\mathrm{d}_{\mathrm{d}}$ (nmol $\left.\mathrm{L}^{-1}\right)$; and seasonal and spatial evolution of (c) $\mathrm{DMSO}_{\mathrm{p}}\left(\mathrm{nmol} \mathrm{L}{ }^{-1}\right),(\mathrm{d}) \mathrm{DMSO}_{\mathrm{d}}\left(\mathrm{nmol} \mathrm{L} \mathrm{L}^{-1}\right)$ in 2018 for the five stations sampled in the Belgian coastal zone (Fig. 1).
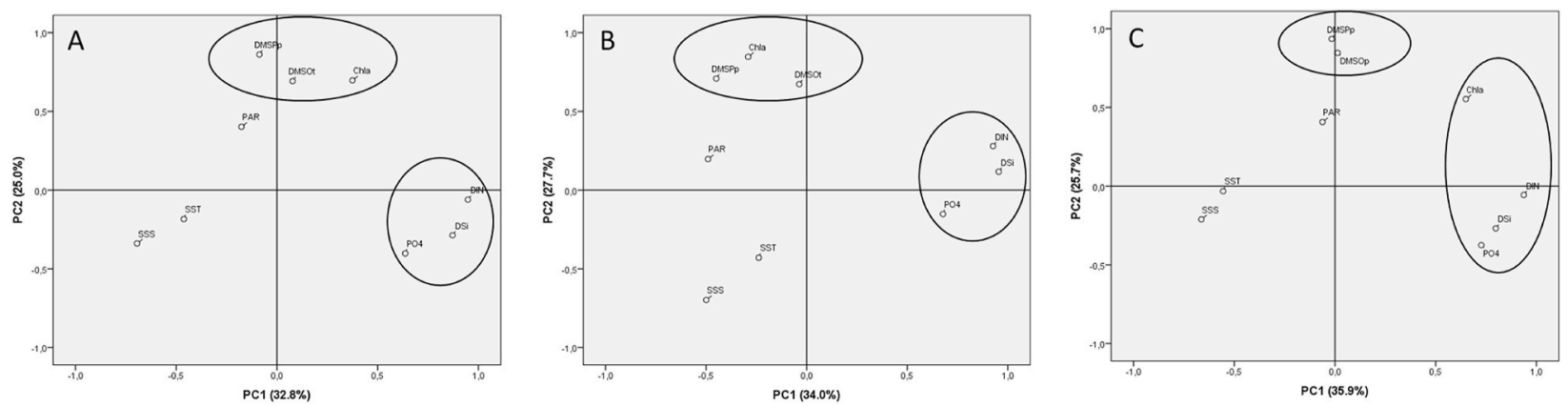

Fig. 7. Principal Component Analysis (PCA) with all the variables after Oblimin rotation for (a) the data from 2016 and 2018 , (b) with data from 2016 and (c) with data from 2018 including Chlorophyll- $a$ (Chl- $a$ ), total dimethylsulfoxide ( $\mathrm{DMSO}_{\mathrm{t}}$ ), particulate dimethylsulfoxide (DMSO $\mathrm{p}_{\mathrm{p}}$ ), particulate dimethylsulfonioproprionate (DMSP $_{\mathrm{p}}$ ), Sea Surface Salinity (SSS), Sea Surface Temperature (SST), Photosynthetic Active Radiation (PAR), Dissolved Inorganic Nitrogen (DIN), Dissolved Silica (DSi), phosphate $\left(\mathrm{PO}_{4}\right)$ in the Belgian coastal zone (Fig. 1).

that was reflected in the PCA.

The Fig. 8a represents the linear regression between $\mathrm{DMSP}_{\mathrm{p}}$ and Chl$a$ for the two years. The slope of the regression of $\mathrm{DMSP}_{\mathrm{p}}$ and Chl- $a$ was higher in 2016 than that in 2018 (Fig. 8a). This is due to the fact that in 2018 many data points for high Chl- $a$ values corresponded to low DMSPproducing diatoms and dinoflagellates (Table 1), while in 2016 the data points for low DMSP-producing species usually exhibited low Chl- $a$. This led to the steeper regression of DMSP $_{\mathrm{p}}$ and Chl- $a$ in 2016 compared to 2018 , as well as lower correlation coefficient in $2018\left(\mathrm{R}^{2}=0.38\right)$ due to more scatter in data points. Yet, when comparing the $\mathrm{DMSP}_{\mathrm{p}}$ and Chl- $a$ correlations separating the Phaeocystis bloom dominated data point from the rest of the year (Fig. $8 \mathrm{~b}$ ), the slopes of the regressions are similar during both years: 42.0 and 53.9 for Phaeocystis in 2018 and 2016, respectively, and 6.8 and 9.1 for the rest of the year in 2018 and 2016, respectively. The first values were in the same range as the $\mathrm{DMSP}_{\mathrm{p}}$ :Chl- $a$ ratio given by Stefels et al. (2007) $(52 \pm 37 \mathrm{mmol}: \mathrm{g})$ or recalculated from published literature with $76.5 \pm 15.0 \mathrm{mmol}: \mathrm{g}$ for the
Prymnesiophyceae $P$. globosa (Table 1). The ratio obtained for the rest of the year corresponds to the ratio given by Stefels et al. (2007) ( $4 \pm 6$ mmol:g) or recalculated in Table $1(3.2 \pm 3.1 \mathrm{mmol}: \mathrm{g})$ for the diatoms. The presence of dinoflagellates was not reflected in the slope of the linear regressions since they were mainly composed by $H$. rotundata characterized by a low DMSP $_{\mathrm{p}}$ :Chl $-a$ ratio of $18.7 \pm 0.9 \mathrm{mmol}: \mathrm{g}$ (Table 1).

The $\mathrm{DMSO}_{\mathrm{p}}$ concentration was significantly correlated with $\mathrm{DMSP}_{\mathrm{p}}$ concentration $(\rho=0.79 ; \mathrm{p}<0.001)$, as also observed in a global dataset by Simó and Vila-Costa (2006). The slope of the regression of $\mathrm{DMSO}_{\mathrm{p}}$ and $\operatorname{DMSP}_{\mathrm{p}}$ (Fig. 9a) $\left(\mathrm{R}^{2}=0.74\right)$ was lower in the BCZ (0.1) than in the global dataset reported by Simó and Vila-Costa (2006) (0.2). This difference cannot be analyzed because Simó and Vila-Costa (2006) did not report the phytoplankton composition. The $\mathrm{DMSO}_{\mathrm{p}}$ :DMSP $\mathrm{p}$ ratio in the $\mathrm{BCZ}$ driven by the data points related to Phaeocystis bloom $(0.16 \pm 0.13)$ was very close to the value of $0.15 \pm 0.09$ reported in the literature for pure Phaeocystis cultures (Hatton and Wilson, 2007; Royer et al., in 

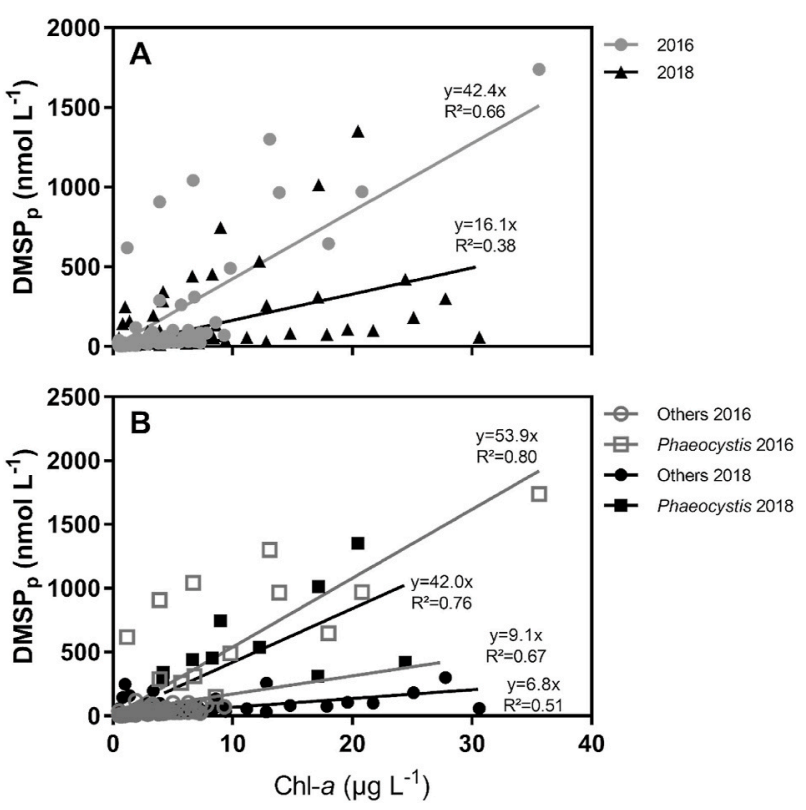

Fig. 8. (a) Particulate dimethylsulfonioproprionate $\left(\mathrm{DMSP}_{\mathrm{p}}\right)\left(\mathrm{nmol} \mathrm{L}{ }^{-1}\right)$ versus Chlorophyll- $a$ (Chl-a) concentration $\left(\mu \mathrm{g} \mathrm{L}^{-1}\right)$ in 2016 and 2018 and (b) DMSP (nmol L ${ }^{-1}$ ) versus Chl- $a$ concentration $\left(\mu \mathrm{g} \mathrm{L}^{-1}\right)$ with discrimination between Phaeocystis and others with data for 2016 and 2018 in the Belgian coastal zone (Fig. 1).

review). $\mathrm{DMSO}_{\mathrm{p}}$ was also highly correlated to Chl- $a$ ( $\rho=0.79$; $\mathrm{p}<$ 0.001) and the slope of the regression was higher for Phaeocystis (3.3 mmol:g) $\left(\mathrm{R}^{2}=0.51\right)$ than for the rest of the year $(1.8 \mathrm{mmol}: \mathrm{g})\left(\mathrm{R}^{2}=\right.$ 0.71 ) (Fig. 9b). The first value was in the same range than those reported in literature for the $\mathrm{DMSO}_{\mathrm{p}}$ :Chl- $a$ ratio with $3.3 \pm 3.6 \mathrm{mmol}: \mathrm{g}$ for the Prymnesiophyceae (Table 2). The second value was higher than the ratio found for the diatoms $(0.8 \pm 0.9 \mathrm{mmol}: \mathrm{g}$; Table 2$)$. The higher value could be explained by the presence of dinoflagellates for which we found DMSO $_{\mathrm{p}}$ :Chl- $a$ ratio of $6.3 \pm 5.9 \mathrm{mmol}: \mathrm{g}$ (Table 2).

\subsection{Phytoplankton diversity and $\mathrm{DMS}(\mathrm{P}, \mathrm{O})$ estimation}

DMSP $_{\mathrm{p}}$ was estimated from the linear regression with Chl- $a$ (DMSP $_{\mathrm{p}}$ $\left(\right.$ nmol L $\left.{ }^{-1}\right)=23.1 *$ Chl- $\left.a\left(\mu \mathrm{L} \mathrm{L}^{-1}\right), \mathrm{R}^{2}=0.46\right)$ computed for the whole dataset (2016 and 2018) and compared with the measured DMSP $P_{p}$. For both years, the magnitude of the calculated Phaeocystis DMSP $_{\mathrm{p}}$ peak was underestimated compared to measurements (Fig. 10a and b). Calculated DMSP $_{\mathrm{p}}$ was also higher than spring and summer observed concentrations in particular in 2018 due to higher Chl- $a$ values (Fig. 10b). As shown by Speeckaert et al. (2018), using a unique DMSP:Chl- $a$ ratio is inappropriate to estimate DMSP concentration associated to either highor low-DMSP producers. We thus used two different DMSP $\mathrm{p}_{\mathrm{p}}$ versus Chl- $a$ relationships to discriminate the two main blooming phytoplankton groups: for Phaeocystis (DMSP $\left.{ }_{\mathrm{p}}\left(\mathrm{nmol} \mathrm{L}^{-1}\right)=48.0 * \mathrm{Chl}-a\left(\mu \mathrm{g} \mathrm{L}^{-1}\right)\right)$ and for diatoms $\left(\right.$ DMSP $\left._{\mathrm{p}}\left(\mathrm{nmol} \mathrm{L}^{-1}\right)=8.0 * \mathrm{Chl}-a\left(\mu \mathrm{g} \mathrm{L}^{-1}\right)\right)$. The use of these specific DMSP $\mathrm{p}:$ Chl- $a$ relationships led to a better fit of modelled DMSP compared to field measurements for both years (Fig. 10a and b).

The same procedure was applied for the $\mathrm{DMSO}_{\mathrm{p}}$ estimation. We compared $\mathrm{DMSO}_{\mathrm{p}}$ computed for the whole dataset in 2018 from the linear regression with Chl- $a\left(\right.$ DMSO $_{\mathrm{p}}\left(\mathrm{nmol} \mathrm{L}^{-1}\right)=2.1 * \mathrm{Chl}-a\left(\mu \mathrm{g} \mathrm{L}^{-1}\right), \mathrm{R}^{2}$ $=0.54$ ). The regression model tends to fit with the observed $\mathrm{DMSO}_{\mathrm{p}}$ except during the Phaeocystis blooming period where it was underestimated but still within the standard deviation (Fig. 10c). When using the relationships deduced from the Fig. $9 \mathrm{~b}$, with one corresponding for the Phaeocystis $\left(\mathrm{DMSO}_{\mathrm{p}}\left(\mathrm{nmol} \mathrm{L}^{-1}\right)=3.3 * \mathrm{Chl}-a\left(\mu \mathrm{g} \mathrm{L}^{-1}\right)\right)$ and one for the diatoms $\left(\right.$ DMSO $_{\mathrm{p}}\left(\mathrm{nmol} \mathrm{L}^{-1}\right)=1.8 *$ Chl- $\left.a\left(\mu \mathrm{g} \mathrm{L}^{-1}\right)\right)$, we mainly observed the same evolution (Fig. 10c).
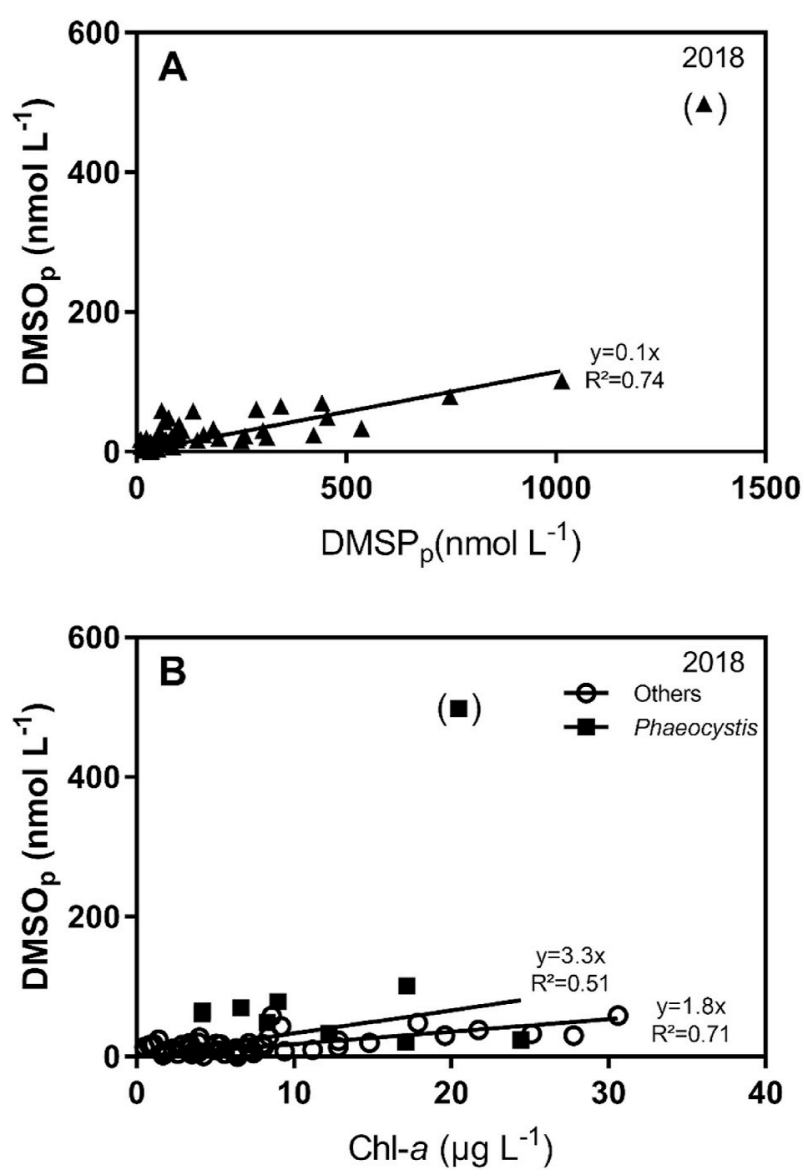

Fig. 9. (a) Particulate dimethylsulfoxide $\left(\mathrm{DMSO}_{\mathrm{p}}\right)\left(\mathrm{nmol} \mathrm{\textrm {L } ^ { - 1 }}\right)$ versus particulate dimethylsulfonioproprionate (DMSP ${ }_{\mathrm{p}}$ ) concentration (nmol L ${ }^{-1}$ ) in 2018 and (b) $\mathrm{DMSO}_{\mathrm{p}}\left(\mathrm{nmol} \mathrm{L}{ }^{-1}\right)$ versus Chlorophyll- $a$ (Chl- $a$ ) concentration $\left(\mu \mathrm{g} \mathrm{L}^{-1}\right)$ with discrimination between Phaeocystis and others with data from 2018 in the Belgian coastal zone (Fig. 1). The linear regressions exclude the outlier data points in brackets.

In conclusion, simple relationships between DMS $(\mathrm{P}, \mathrm{O})_{\mathrm{p}}$ and Chl- $a$ are not sufficiently robust to describe the seasonal variability of DMS(P, $\mathrm{O})_{\mathrm{p}}$. We thus recommend considering two separate DMS(P,O)-Chl- $a$ relationships for low and high-DMSP producing groups to estimate DMS(P, O) $\mathrm{p}$ based on Chl- $a$ in global models.

\section{Conclusions}

Phytoplankton biomass in the BCZ was higher during the diatom blooming period in spring 2018 than 2016, and to a lesser extent, in August 2018 than 2016. The difference among years in spring was explained by lower SST during winter, higher nutrients supply coming from the Scheldt estuary and better light conditions in 2018 compared to 2016. The difference among years in August seemed related to higher SST in 2018 compared to 2016. Despite these major differences in phytoplankton biomass, the seasonal and spatial DMS $(\mathrm{P}, \mathrm{O})_{\mathrm{p}}$ patterns were similar in 2016 and 2018. This was explained by the peak of biomass occurring both years in spring due to Phaeocystis. Phaeocystis is a high-DMS $(\mathrm{P}, \mathrm{O})$ producer and dominates the annual $\mathrm{DMSP}_{\mathrm{p}}$ production in the BCZ. On the contrary, low-DMSP producing diatom and dinoflagellate species dominated the spring and summer bloom for which we observed strong differences in Chl- $a$ between both years. This illustrates why Chl- $a$ concentration alone could not be used to describe the DMS(P, O) $p$ variations. The phytoplankton diversity had to be taken into consideration to analyze and better predict the DMS $(\mathrm{P}, \mathrm{O})_{\mathrm{p}}$ variations. The impact of current or future phytoplankton biomass changes on DMS 

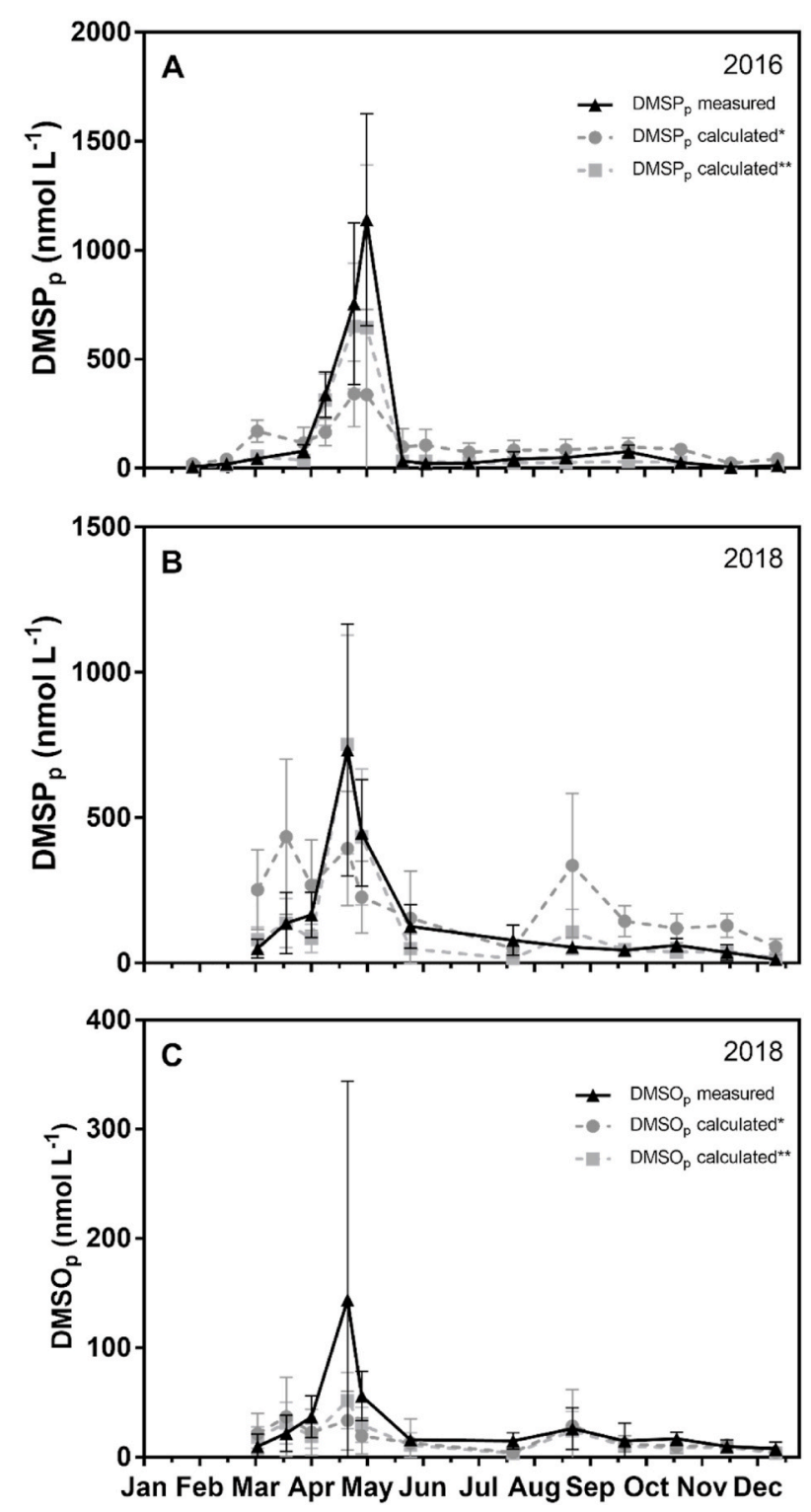

Fig. 10. Seasonal evolution in the Belgian coastal zone of average ( \pm standard deviation) particulate dimethylsulfonioproprionate (DMSP ${ }_{\mathrm{p}}$ ) measured ( $\mathrm{nmol} \mathrm{L}^{-}$ ${ }^{1}$ ) (in black) and DMSP $_{\mathrm{p}}$ calculated* based on Chlorophyll- $a$ (Chl- $a$ ) concentration using a relationship for all phytoplankton species DMSP $_{\mathrm{p}}\left(\mathrm{nmol} \mathrm{L}^{-1}\right)=$ $25.1 *$ Chl- $\left.a\left(\mu \mathrm{g} \mathrm{L}^{-1}\right)\right]$ or DMSP $\mathrm{p}$ calculated** using a relationship for the diatoms $\left[\mathrm{DMSP}_{\mathrm{p}}\left(\mathrm{nmol} \mathrm{L}{ }^{-1}\right)=8.0 * \mathrm{Chl}-a\left(\mu \mathrm{g} \mathrm{L}^{-1}\right)\right]$ and another one for Phaeocystis globosa [DMSP $_{\mathrm{p}}\left(\mathrm{nmol} \mathrm{L}{ }^{-1}\right)=48.0 *$ Chl- $a\left(\mu \mathrm{g} \mathrm{L}^{-1}\right)$ ] for (a) 2016 and (b) 2018. (c) Seasonal evolution of particulate dimethylsulfoxide $\left(\mathrm{DMSO}_{\mathrm{p}}\right)$ measured (nmol L ${ }^{-1}$ ) (in black) and $\mathrm{DMSO}_{\mathrm{p}}$ calculated* based on Chl- $a$ using a relationship for all phytoplankton species $\left[\mathrm{DMSO}_{\mathrm{p}}\left(\mathrm{nmol} \mathrm{L}^{-1}\right)=2.1 *\right.$ Chl- $\left.a\left(\mu \mathrm{g} \mathrm{L}^{-1}\right)\right]$ or $\mathrm{DMSO}_{\mathrm{p}}$ calculated $* *$ using a relationship for the diatoms $\left[\mathrm{DMSO}_{\mathrm{p}}\left(\mathrm{nmol} \mathrm{L} \mathrm{L}^{-1}\right)=\right.$ $1.8 *$ Chl- $\left.a\left(\mu \mathrm{g} \mathrm{L}^{-1}\right)\right]$ and another one for Phaeocystis globosa DMSO $_{\mathrm{p}}\left(\mathrm{nmol} \mathrm{L}^{-1}\right)$ $=3.3 *$ Chl- $\left.a\left(\mu \mathrm{g} \mathrm{L}^{-1}\right)\right]$ for 2018 .

$(\mathrm{P}, \mathrm{O})_{\mathrm{p}}$ marine concentrations will thus mainly depend on the species composition rather than the total phytoplankton biomass.

Coastal marine areas are expected to show changes in phytoplankton biomass in response to several human pressures such as nutrient inputs and changes in temperature that can also affect $\mathrm{DMS}(\mathrm{P}, \mathrm{O})_{\mathrm{p}}$ concentration (and possibly DMS emissions). We pointed out the significance of considering two separate DMS $(\mathrm{P}, \mathrm{O})_{\mathrm{p}}-\mathrm{Chl}-\boldsymbol{a}$ relationships for low and high-DMSP producing species to properly estimate the DMS $(\mathrm{P}, \mathrm{O})_{\mathrm{p}}$ concentrations. Better constrain the DMS $(\mathrm{P}, \mathrm{O})_{\mathrm{p}}$ in the water column linked to the phytoplankton diversity and abiotic parameters will ultimately lead to improvements in the modelling of the ocean-atmosphere DMS flux and its potential climate impact.

\section{Declaration of competing interest}

The authors declare that they have no known competing financial interests or personal relationships that could have appeared to influence the work reported in this paper.

\section{Acknowledgements}

We are grateful to the crew of the RV Simon Stevin for assistance during the cruises, to André Cattrijsse and Jonas Mortelmans (VLIZ) for organizing the schedule of cruises. Nutrient data were acquired as part of the VLIZ contribution to the LifeWatch ESFRI. This project has received funding from the European Union's Horizon 2020 research and innovation program under the Marie Skłodowska-Curie grant agreement No 766327. The GC was acquired with funds from the Fonds National de la Recherche Scientifique (FNRS) (2.4.637.10). NG and CR received financial support from the Fonds David et Alice Van Buuren. CR has a PhD grant from the FRIA (Fund for Research Training in Industry and Agriculture, FNRS). AVB is a research director at the FNRS.

\section{References}

Andreae, M.O., Barnard, W.R., 1984. The marine chemistry of dimethylsulfide. Mar. Chem. 14, 267-279. https://doi.org/10.1016/0304-4203(84)90047-1.

Barton, S., et al., 2018. Universal Metabolic Constraints on the Thermal Tolerance of Marine Phytoplankton. https://doi.org/10.1101/358002. http://biorxiv.org/lookup /doi/10.1101/358002.

Borges, A.V., Royer, C., Martin, J.L., Champenois, W., Gypens, N., 2019. Response of marine methane dissolved concentrations and emissions in the Southern North Sea to the European 2018 heatwave. Continent. Shelf Res. 190, 104004.

Bucciarelli, E., Sunda, W.G., 2003. Influence of CO2, nitrate, phosphate, and silicate limitation on intracellular dimethylsulfoniopropionate in batch cultures of the coastal diatom Thalassiosira pseudonana. Limnol. Oceanogr. 48, 2256-2265.

Bucciarelli, E., et al., 2013. Increased intracellular concentrations of DMSP and DMSO in iron-limited oceanic phytoplankton Thalassiosira oceanica and Trichodesmium erythraeum. Limnol. Oceanogr. 58, 1667-1679.

Champenois, W., Borges, A.V., 2019. Determination of dimethylsulfoniopropionate and dimethylsulfoxide in Posidonia oceanica leaf tissue. MethodsX 6, 56-62.

Charlson, R.J., Lovelock, J.E., Andreae, M.O., Warren, S.G., 1987. Oceanic phytoplankton, atmospheric sulphur, cloud albedo and climate. Nature 326, 655-661.

Cooney, E.C., 2016. The effect of high-intensity visible light on the bloom niches of the phototrophic dinoflagellates Alexandrium fundyense and Heterocapsa rotundata. WWU Grad. Sch. Collect. 529.

Cooney, E.C., Fredrickson, K.A., Bright, K.J., Strom, S.L., 2019. Contrasting effects of high-intensity photosynthetically active radiation on two bloom-forming dinoflagellates. J. Phycol. 55, 1082-1095.

Curran, M.A.J., Jones, G.B., 1998. Spatial distribution of dimethylsulfide and dimethylsulfoniopropionate in the Australasian sector of the Southern Ocean. J. Geophys. Res. 103, 16677-16689.

Dacey, J.W.H., Blough, N.V., 1987. Hydroxide decomposition of dimethylsulfoniopropionate to form dimethylsulfide. Geophys. Res. Lett. 14, 1246-1249.

Del Valle, D.A., et al., 2011. Effect of acidification on preservation of DMSP in seawater and phytoplankton cultures: evidence for rapid loss and cleavage of DMSP in samples containing Phaeocystis sp. Mar. Chem. 124, 57-67.

Deschaseaux, E.S.M., et al., 2014. Dimethylsulphoxide (DMSO) in biological samples: a comparison of the $\mathrm{TiCl}_{3}$ and $\mathrm{NaBH}_{4}$ reduction methods using headspace analysis. Mar. Chem. 164, 9-15.

Desmit, X., et al., 2019. Changes in chlorophyll concentration and phenology in the North Sea in relation to de-eutrophication and sea surface warming. Limnol. Oceanogr. lno 11351. https://doi.org/10.1002/lno.11351.

Edwards, K.F., Thomas, M.K., Klausmeier, C.A., Litchman, E., 2016. Phytoplankton growth and the interaction of light and temperature: a synthesis at the species and community level: light-Temperature Interactions. Limnol. Oceanogr. 61, 1232-1244.

Flanders Marine Institute (VLIZ), 2019. Belgium: LifeWatch Observatory Data: Nutrient, Pigment, Suspended Matter and Secchi Measurements in the Belgian Part of the North Sea. https://doi.org/10.14284/328.

Geider, R.J., 1987. Light and temperature dependence of the carbon to chlorophyll a ratio in microalgae and cyanobacteria: implications for physiology and growth of phytoplankton. New Phytol. 106, 1-34.

Goss-Sampson, M.A., 2018. Statistical Analysis in JAsP: A Guide for Students.

Gypens, N., Borges, A.V., Speeckaert, G., Lancelot, C., 2014. The dimethylsulfide cycle in the eutrophied southern North sea: a model study integrating phytoplankton and bacterial processes. PloS One 9, e85862. 
Hatton, A.D., Wilson, S.T., 2007. Particulate dimethylsulphoxide and dimethylsulphoniopropionate in phytoplankton cultures and Scottish coastal waters. Aquat. Sci. 69, 330-340.

Hunter-Cevera, K.R., et al., 2016. Physiological and ecological drivers of early spring blooms of a coastal phytoplankter. Science 354, 326-329.

Keller, M.D., Bellows, W.K., Guillard, R.R.L., 1989. Dimethyl sulfide production in marine phytoplankton. In: Saltzman, E.S., Cooper, W.J. (Eds.), Biogenic Sulfur in the Environment. American Chemical Society, Washington DC, pp. 167-182.

Kiene, R.P., Gerard, G., 1994. Determination of trace levels of dimethylsulphoxide (DMSO) in seawater and rainwater. Mar. Chem. 47, 1-12.

Kiene, R.P., Slezak, D., 2006. Low dissolved DMSP concentrations in seawater revealed by small volume gravity filtration and dialysis sampling. Limnol Oceanogr. Methods 4, 80-95.

Kinsey, J.D., Kieber, D.J., 2016. Microwave preservation method for DMSP, DMSO, and acrylate in unfiltered seawater and phytoplankton culture samples. Limnol Oceanogr. Methods 14, 196-209.

Kirst, G.O., et al., 1991. Dimethylsulfoniopropionate (DMSP) in icealgae and its possible biological role. Mar. Chem. 35, 381-388.

Kirst, G.O., 1996. Osmotic adjustments in phytoplankton and macroalgae: the use of dimethylsulfoniopropionate (DMSP). In: Kiene, R.P., Visscher, P., Keller, M., Kirst, G. O. (Eds.), Biological and Environmental Chemistry of DMSP and Related Sulfonium Compounds. Plenum, New York, pp. 121-129.

Litchman, E., Klausmeier, C.A., 2001. Competition of Phytoplankton under fluctuating light. Am. Nat. 157 (2), 170-187.

Magnusson, L., Ferranti, L., Vamborg, F., 2018. Forecasting the 2018 European heatwave. ECMWF newsletter, 157, p. 4. https://www.ecmwf.int/en/newsletter/1 57/news/forecasting-2018-european-heatwave. (Accessed 7 March 2019).

McMurdie, P.J., Holmes, S., 2013. Phyloseq: an R package for reproducible interactive analysis and graphics of microbiome census data. PloS One 8, e61217.

McParland, E.L., Levine, N.M., 2019. The role of differential DMSP production and community composition in predicting variability of global surface DMSP concentrations. Limnol. Oceanogr. 64, 757-773.

Menden-Deuer, S., Lessard, E.J., 2000. Carbon to volume relationships for dinoflagellates, diatoms, and other protist plankton. Limnol. Oceanogr. 45, 569-579.

Montagnes, D.J.S., Franklin, M., 2001. Effect of temperature on diatom volume, growth rate, and carbon and nitrogen content: reconsidering some paradigms. Limnol. Oceanogr. 46, 2008-2018.

Mortelmans, J., et al., 2019. Nutrient, pigment, suspended matter and turbidity measurements in the Belgian part of the North Sea. Sci. Data 6, 22.

Nohe, A., et al., 2020. Marked changes in diatom and dinoflagellate biomass, composition and seasonality in the Belgian Part of the North Sea between the 1970s and 2000s. Sci. Total Environ. 716, 136316.

Olenina, I., et al., 2006. Biovolumes and size-classes of phytoplankton in the Baltic Sea. HELCOM Balt. Sea Environ. Proc. 106.

Prins, T.C., Desmit, X., Baretta-Bekker, J.G., 2012. Phytoplankton composition in Dutch coastal waters responds to changes in riverine nutrient loads. J. Sea Res. 73, 49-62. https://doi.org/10.1016/j.seares.2012.06.009.

Quinn, P.K., Bates, T.S., 2011. The case against climate regulation via oceanic phytoplankton sulphur emissions. Nature 480, 51-56.

Richardson, A.J., Schoeman, D.S., 2004. Climate impact on plankton ecosystems in the Northeast Atlantic. Science 305, 1609-1612. https://doi.org/10.1126/ science.1100958.

Rousseau, V., 2000. Dynamics of Phaeocystis and Diatom Blooms in the Eutrophicated Coastal Waters of the Southern Bight of the North Sea. Ph.D. thesis. Université Libre de Bruxelles, 205pp.

Rousseau, V., Leynaert, A., Daoud, N., Lancelot, C., 2002. Diatom succession, silicification and silicic acid availability in Belgian coastal waters (Southern North Sea). Mar. Ecol. Prog. Ser. 236, 61-73.

Rousseau, V., Mathot, S., Lancelot, C., 1990. Calculating carbon biomass of Phaeocystis sp. from microscopic observations. Mar. Biol. 107, 305-314.
Schabhüttl, S., et al., 2013. Temperature and species richness effects in phytoplankton communities. Oecologia 171, 527-536.

Seymour, J.R., Simo, R., Ahmed, T., Stocker, R., 2010. Chemoattraction to dimethylsulfoniopropionate throughout the marine microbial food web. Science 329, 342-345.

Simó, R., Vila-Costa, M., 2006. Ubiquity of algal dimethylsulfoxide in the surface ocean: geographic and temporal distribution patterns. Mar. Chem. 100, 136-146.

Simó, R., Hatton, A., Malin, G., Liss, P., 1998. Particulate dimethyl sulphoxide in seawater: production by microplankton. Mar. Ecol. Prog. Ser. 167, 291-296.

Sommer, U., Lewandowska, A., 2011. Climate change and the phytoplankton spring bloom: warming and overwintering zooplankton have similar effects on phytoplankton. Global Change Biol. 17, 154-162.

Sommer, U., et al., 2012. Beyond the plankton ecology group (PEG) model: mechanisms driving plankton succession. Annu. Rev. Ecol. Evol. Syst. 43, 429-448.

Speeckaert, G., Borges, A.V., Gypens, N., 2019. Salinity and growth effects on dimethylsulfoniopropionate (DMSP) and dimethylsulfoxide (DMSO) cell quotas of Skeletonema costatum, Phaeocystis globosa and Heterocapsa triquetra. Estuar. Coast Shelf Sci. 226, 106275.

Speeckaert, G., Borges, A.V., Champenois, W., Royer, C., Gypens, N., 2018. Annual cycle of dimethylsulfoniopropionate (DMSP) and dimethylsulfoxide (DMSO) related to phytoplankton succession in the Southern North Sea. Sci. Total Environ. 622-623, 362-372.

Stefels, J., 2009. Determination of DMS, DMSP, and DMSO in Seawater. Practical Guidelines for the Analysis of Seawater, p. 223.

Stefels, J., 2000. Physiological aspects of the production and conversion of DMSP in marine algae and higher plants. J. Sea Res. 43, 183-197.

Stefels, J., Steinke, M., Turner, S., Malin, G., Belviso, S., 2007. Environmental constraints on the production and removal of the climatically active gas dimethylsulphide (DMS) and implications for ecosystem modelling. Biogeochemistry 83, 245-275.

Strickland, J.D.H., Parsons, T.R., 1972. A practical handbook of seawater analysis. Pract. Handb. Seawater Anal. 167, 185.

Striebel, M., Schabhüttl, S., Hodapp, D., Hingsamer, P., Hillebrand, H., 2016. Phytoplankton responses to temperature increases are constrained by abiotic conditions and community composition. Oecologia 182, 815-827.

Strom, S., et al., 2003. Chemical defense in the microplankton I: feeding and growth rates of heterotrophic protists on the DMS-producing phytoplankter Emiliania huxleyi. Limnol. Oceanogr. 48, 217-229.

Suikkanen, S., Laamanen, M., Huttunen, M., 2007. Long-term changes in summer phytoplankton communities of the open northern Baltic Sea. Estuar. Coast Shelf Sci. $71,580-592$.

Sunda, W., Kieber, D.J., Kiene, R.P., Huntsman, S., 2002. An antioxidant function for DMSP and DMS in marine algae. Nature 418, 317-320.

Townsend, D., Keller, M., 1996. Dimethylsulfide (DMS) and dimethylsulfoniopropionate (DMSP) in relation to phytoplankton in the Gulf of Maine. Mar. Ecol. Prog. Ser. 137, 229-241.

Tynes, C., 2013. Molecular Investigation of Candidate Genes for the Biosynthetic Pathway for Dimethylsulfoniopropionate (DMSP) in the Diatom Thalassiosira Pseudonana. Department of Biology at the Norwegian University of Science and Technology (NTNU).

van Beusekom, J.E.E., Loebl, M., Martens, P., 2009. Distant riverine nutrient supply and local temperature drive the long-term phytoplankton development in a temperate coastal basin. J. Sea Res. 61, 26-33. https://doi.org/10.1016/J. SEARES.2008.06.005.

Wiltshire, K.H., et al., 2008. Resilience of North Sea phytoplankton spring bloom dynamics: an analysis of long-term data at Helgoland Roads. Limnol. Oceanogr. 53, 1294-1302.

Wolfe, G.V., Steinke, M., Kirst, G.O., 1997. Grazing-activated chemical defence in a unicellular marine alga. Nature 387, 894-897. 